Supporting Information

\title{
Activating Imides with Triflic Acid: a General Intramolecular Aldol Condensation Strategy Toward Indolizidine, Quinolizidine and Valmerins Alkaloids
}

Yovanny Quevedo-Acosta, ${ }^{\dagger, \neq}$ Igor D. Jurberg, ${ }^{* \dagger}$ and Diego Gamba-Sánchez ${ }^{\star \ddagger}$

† Institute of Chemistry, State University of Campinas, Rua Monteiro Lobato 270, 13083-862, Campinas, SP, Brazil

¥ Laboratory of Organic Synthesis, Bio and Organocatalysis, Chemistry Department, Universidad de los Andes, Cra 1 No. 18A-12 Q:305. 111711, Bogotá, Colombia 
Table of Contents

1. General information S3

2. Additional Information $\mathrm{S} 4$

2.1 Optimization of Reaction Conditions $\quad$ S4

2.2 Additional Schemes $\quad$ S5

3. Experimental Procedures $\quad \mathrm{S} 6$

4. X-Ray Crystal Structures $\quad \mathrm{S} 18$

5. NMR spectra $\quad$ S20

6. References $S 42$ 


\section{General information}

All reactions were conducted in oven-dried glassware under an inert atmosphere of dry nitrogen. All reagents were used as received from commercial suppliers, unless otherwise stated. Reactions that required heating were performed using a heating mantle or appropriate heating blocks depending on the reaction flask size. All solvents were distilled from appropriate drying agents prior to use. ${ }^{1} \mathrm{H}$ NMR spectra were recorded at 400 or $500 \mathrm{MHz}$ on a Bruker AV-400 or AV-500 spectrometers, respectively. ${ }^{13} \mathrm{C}$ NMR spectra were recorded at 100 or $125 \mathrm{MHz}$ on a 400 or $500 \mathrm{MHz}$ on a Bruker AV-400 or AV-500 spectrometers, respectively. NMR spectra were recorded in deuterated chloroform $\left(\mathrm{CDCl}_{3}\right)$ solutions, chemical shifts are given in parts per million (ppm, $\delta$ ), referenced to the TMS, solvent peak of $\mathrm{CDCl}_{3}$ defined at $\delta$ $=7.26 \mathrm{ppm}\left({ }^{1} \mathrm{H}\right.$ NMR $)$ and $\delta=77.00\left({ }^{13} \mathrm{C}\right.$ NMR $)$. Data abbreviations are reported as follows: $\delta$, chemical shift; $s$, singlet; $d$, doublet; $t$, triplet; $q$, quartet and $m$, multiplet. Coupling constants are quoted in Hertz (J). Infrared (IR) spectra were collected on an Agilent Cary 630 FTIR, using a diamond ATR sensor or Thermo Nicolet-Nexus FTIR with Pike Miracle ATR cell spectrometers, and are reported in terms of absorption frequency $\left(\mathrm{n}, \mathrm{cm}^{-1}\right)$. Mass spectrometric determinations were carried out on a Thermo Scientific LTQ FT Ultra Q Exactive Orbitrap or Agilent 5973 spectrometers, working with an electron spray ionization (ESI). Reactions were monitored by thin layer chromatography (TLC) on Silica gel $60 F_{254}$ aluminium plates. TLC plates were visualized using ultraviolet (UV) light at $254 \mathrm{~nm}$ or stained with anisaldehyde, vanillin or $\mathrm{KMnO}_{4}$ solutions. Flash column chromatography was performed with silica gel $60 \AA$ ( 230 - 400 mesh) from Aldrich, using the stated mixture of solvents. 


\section{Additional Information}

\subsection{Optimization of Reaction Conditions}

Table S1. Optimization of the Intramolecular Aldol Condensation.

\begin{tabular}{|c|c|c|c|c|}
\hline entry & solvent & promoter & $\mathrm{T}\left({ }^{\circ} \mathrm{C}\right)$ & yield of $14(\%)^{a}$ \\
\hline 1 & 1,2-DCE & - & 83 & no reaction \\
\hline 2 & 1,2-DCE & $\mathrm{Sc}(\mathrm{OTf})_{3}$ (1 equiv.) & 83 & $26 \%$ \\
\hline 3 & 1,2-DCE & $\mathrm{BF}_{3} . \mathrm{OEt}_{2}$ (1 equiv.) & 83 & traces \\
\hline 4 & 1,2-DCE & $\mathrm{SnCl}_{4}$ (1 equiv.) & 83 & no reaction \\
\hline 5 & 1,2-DCE & pTSA $\cdot \mathrm{H}_{2} \mathrm{O}$ (1 equiv.) & 83 & $7 \%$ \\
\hline 6 & 1,2-DCE & TfOH (1 equiv.) & 83 & $70 \%$ \\
\hline 7 & 1,2-DCE & Aniline (1 equiv.) & 83 & traces \\
\hline 8 & 1,2-DCE & Benzylamine (1 equiv.) & 83 & $4 \%$ \\
\hline 9 & 1,2-DCE & Piperidine (1 equiv.) & 83 & $2 \%$ \\
\hline 10 & 1,2-DCE & Morpholine (1 equiv.) & 83 & traces \\
\hline 11 & 1,2-DCE & Pyrrolidine (1 equiv.) & 83 & $15 \%$ \\
\hline 12 & 1,2-DCE & $\mathrm{KOH}$ (1 equiv.) & 83 & no reaction \\
\hline 13 & 1,2-DCE & 4-DMAP (1 equiv.) & 83 & no reaction \\
\hline 14 & $\mathrm{H}_{2} \mathrm{O}$ & TfOH (1 equiv.) & 100 & no reaction \\
\hline 15 & $\mathrm{MeOH}$ & TfOH (1 equiv.) & 65 & no reaction \\
\hline 16 & DMF & TfOH (1 equiv.) & 153 & no reaction \\
\hline 17 & $\mathrm{MeCN}$ & TfOH (1 equiv.) & 82 & no reaction \\
\hline 18 & Acetone & TfOH (1 equiv.) & 56 & no reaction \\
\hline 19 & THF & TfOH (1 equiv.) & 65 & no reaction \\
\hline 20 & AcOEt & TfOH (1 equiv.) & 77 & $40 \%$ \\
\hline 21 & $\mathrm{DCM}$ & TfOH (1 equiv.) & 40 & $2 \%$ \\
\hline 22 & $\mathrm{Et}_{2} \mathrm{O}$ & TfOH (1 equiv.) & 34 & $0 \%$ \\
\hline 23 & Hexanes & TfOH (1 equiv.) & 69 & $12 \%$ \\
\hline 24 & Toluene & TfOH (1 equiv.) & 90 & $90 \%$ \\
\hline 25 & Toluene & $\mathrm{TfOH}$ (0.1 equiv.) & 90 & no reaction \\
\hline 26 & Toluene & TfOH (0.2 equiv.) & 90 & $15 \%$ \\
\hline 27 & Toluene & $\mathrm{TfOH}$ ( 0.4 equiv.) & 90 & $14 \%$ \\
\hline 28 & Toluene & TfOH (1.5 equiv.) & 90 & $71 \%$ \\
\hline 29 & Toluene & TfOH (2 equiv.) & 90 & $60 \%$ \\
\hline
\end{tabular}

aEstimated based on the ${ }^{1} \mathrm{H}$ NMR analysis of the crude reaction mixture using 1,3,5-trimethoxybenzene as internal reference. 


\subsection{Additional Schemes}

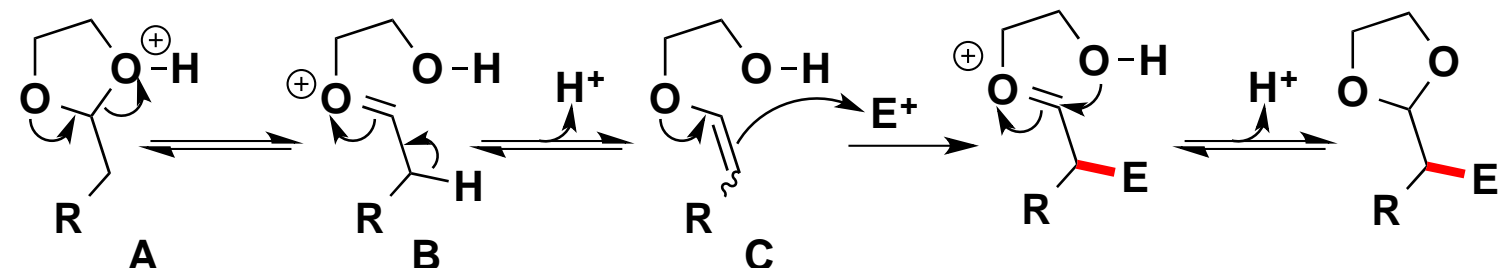

Scheme S1. Working hypotesis for $\alpha$-functionalization of acetals under acidic conditions.

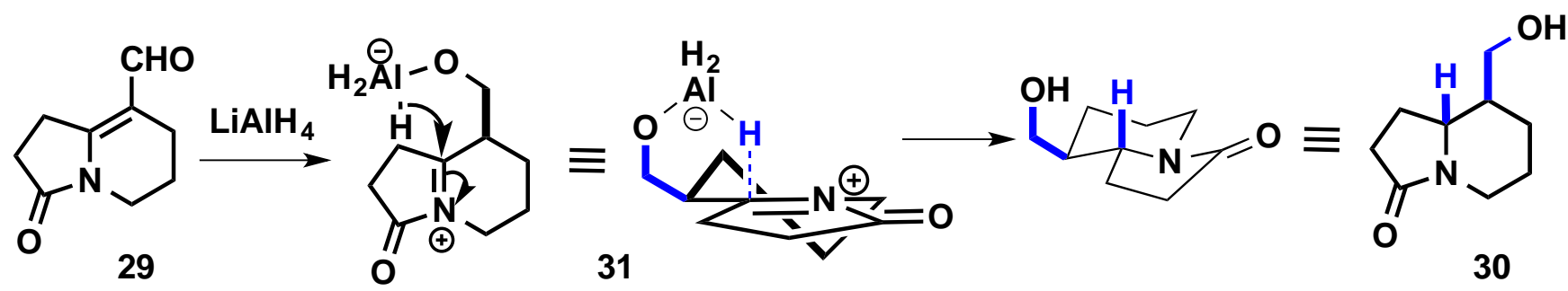

Scheme S2. Proposed rationalization for high diaestereoselectivity. 


\section{Experimental Procedures}

\section{1-(3-oxobutyl)pyrrolidine-2,5-dione (13)}

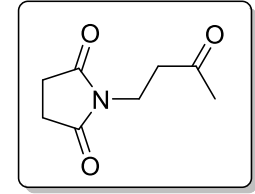

Adapted from a procedure by Rasapalli and co-workers. ${ }^{1}$ To a solution of succinimide $11(586 \mathrm{mg}, 5.91 \mathrm{mmol})$ in AcOEt $(6.0 \mathrm{~mL})$ is added EtONa (20 $\mathrm{mg}, 0.29 \mathrm{mmol})$ under argon atmosphere. After 15 minutes stirring at room temperature, methylvinyl ketone 12 (MVK) $(543 \mu \mathrm{L}, 6.50 \mathrm{mmol})$ is added and the resulting mixture is refluxed at $77^{\circ} \mathrm{C}$ for 16 hours. Then, the reaction is cooled to room temperature and water is added. The aqueous phase is extracted with AcOEt $(3 \times 5 \mathrm{~mL})$, dried over anhydrous $\mathrm{MgSO}_{4}$, filtered and concentrated under reduced pressure to afford the title compound as a white solid: $1.00 \mathrm{~g}, 100 \%$.

Alternative procedure: To a solution of succinimide $11(1.50 \mathrm{~g}, 15.13 \mathrm{mmol})$ and 4-DMAP (93 mg, $0.75 \mathrm{mmol})$ in $10 \mathrm{~mL}$ of water, MVK $12(1.90 \mathrm{~mL}, 22.7 \mathrm{mmol})$ is added. The resulting solution is vigorously stirred at room temperature for 8 hours. Then, it is extracted with AcOEt $(3 \times 5 \mathrm{~mL})$, dried over anhydrous $\mathrm{MgSO}_{4}$, filtered and concentrated under reduced pressure to afford the title compound as a white solid: $2.30 \mathrm{~g}, 90 \%$.

In both of the previous cases, the spectroscopic data are consistent with the literature. ${ }^{2}$

${ }^{1} \mathrm{H}$ NMR $\left(400 \mathrm{MHz}, \mathrm{CDCl}_{3}\right) \delta: 3.77(\mathrm{t}, J=7.4 \mathrm{~Hz}, 2 \mathrm{H}), 2.75(\mathrm{t}, J=7.4 \mathrm{~Hz}, 2 \mathrm{H}), 2.69(\mathrm{~s}, 4 \mathrm{H})$, $2.15(\mathrm{~s}, 3 \mathrm{H})$.

${ }^{13} \mathrm{C}$ NMR $\left(100 \mathrm{MHz}, \mathrm{CDCl}_{3}\right)$ ס: 205.7, 177.0, 40.6, 33.8, 29.9, 28.1.

M.P.: $49^{\circ} \mathrm{C}$.

IR (neat, ATR): 2965, 2928, 1773, 1683, 1423, 1367, 1342, 1160.

HRMS (ESI+): Calcd. for [ $\left.\mathrm{C}_{8} \mathrm{H}_{11} \mathrm{NO}_{3}+\mathrm{H}\right]^{+}:$170.0812, found: 170.0812 .

\section{1,2,5,6-tetrahydroindolizine-3,7-dione (14)}

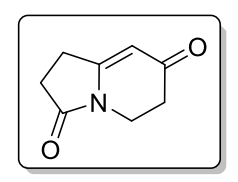

To a stirred solution of 1-(3-oxobutyl)pyrrolidine-2,5-dione 13 (1.29 g, 7.64 $\mathrm{mmol}$ ) or 1-(2-(2-methyl-1,3-dioxolan-2-yl)ethyl)pyrrolidine-2,5-dione 23 (1.63 g, $7.64 \mathrm{mmol})$ in toluene $(20 \mathrm{~mL}), \mathrm{TfOH}(708 \mu \mathrm{L}, 8.02 \mathrm{mmol})$ is added, and the mixture is heated at $90^{\circ} \mathrm{C}$ for $16 \mathrm{~h}$. Then, the reaction is quenched with $\mathrm{NaHCO}_{3}(0.77 \mathrm{~g}, 9.17$ $\mathrm{mmol}$ ) and $5 \mathrm{~mL}$ of water. The organic phase is extracted with DCM ( $3 \times 5 \mathrm{~mL})$, dried over anhydrous $\mathrm{MgSO}_{4}$ and concentrated under reduced pressure. Purification by flash column 
chromatography (95:5 DCM:MeOH) affords the title compound as a brown solid: $1.04 \mathrm{~g}, 90 \%$. The spectroscopic data are identical to those previously described. ${ }^{3}$

${ }^{1} \mathrm{H}$ NMR $\left(500 \mathrm{MHz}, \mathrm{CDCl}_{3}\right) \delta: 5.33(\mathrm{~s}, 1 \mathrm{H}), 3.89(\mathrm{t}, J=7.7 \mathrm{~Hz}, 2 \mathrm{H}), 2.93-2.88(\mathrm{~m}, 2 \mathrm{H}), 2.66-$ $2.62(\mathrm{~m}, 2 \mathrm{H}), 2.55(\mathrm{t}, J=7.7 \mathrm{~Hz}, 2 \mathrm{H})$.

${ }^{13} \mathrm{C}$ NMR $\left(125 \mathrm{MHz}, \mathrm{CDCl}_{3}\right)$ ס: 192.3, 174.8, 161.6, 102.8, 37.8, 33.9, 28.0, 23.6.

M.P.: $71^{\circ} \mathrm{C}$.

IR (neat, ATR): 3071, 2941, 1724, 1648, 1592, 1335, 1212, 1147.

HRMS (ESI+): Calcd. for $\left[\mathrm{C}_{8} \mathrm{H}_{9} \mathrm{NO}_{2}+\mathrm{H}\right]^{+}:$152.0706, found: 152.0706 .

\section{Hexahydroindolizin-3(2H)-one (15)}

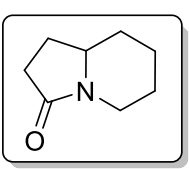

A mixture containing $100 \mathrm{mg}(0.66 \mathrm{mmol})$ of 1,2,5,6-tetrahydroindolizine-3,7dione $14,35 \mathrm{mg}(0.033 \mathrm{mmol})$ of $10 \% \mathrm{Pd} / \mathrm{C}$ and $5 \mathrm{~mL}$ of $\mathrm{HCl}(1.0 \mathrm{M}$ in $\mathrm{EtOH})$ is subjected to a $\mathrm{H}_{2}$ atmosphere $(1 \mathrm{~atm})$ for $3.5 \mathrm{~h}$. Then, the reaction mixture is filtered through a pad of celite and the solvent is removed under reduced pressure. The residue is purified by flash column chromatography (95:5 AcOEt:MeOH) to afford the title compound as an yellow oil: $81 \mathrm{mg}, 88 \%$. The spectroscopic data are identical to those previosly described. ${ }^{4}$

${ }^{1} \mathrm{H}$ NMR $\left(400 \mathrm{MHz}, \mathrm{CDCl}_{3}\right) \delta: 4.15-4.07(\mathrm{~m}, 1 \mathrm{H}), 3.39(\mathrm{dtd}, J=10.7 \mathrm{~Hz}, J=7.4 \mathrm{~Hz}, J=3.4$ $\mathrm{Hz}, 1 \mathrm{H}), 2.61(\mathrm{td}, J=12.8 \mathrm{~Hz}, J=3.1 \mathrm{~Hz}, 1 \mathrm{H}), 2.38-2.31(\mathrm{~m}, 2 \mathrm{H}), 2.19(\mathrm{dt}, J=13.2 \mathrm{~Hz}, J=$ $7.4 \mathrm{~Hz}, 1 \mathrm{H}), 1.91-1.82(\mathrm{~m}, 2 \mathrm{H}), 1.68(\mathrm{~d}, J=12.8 \mathrm{~Hz}, 1 \mathrm{H}), 1.62-1.51(\mathrm{~m}, 1 \mathrm{H}), 1.44-1.26$ $(\mathrm{m}, 2 \mathrm{H}), 1.23-1.09(\mathrm{~m}, 1 \mathrm{H})$.

${ }^{13} \mathrm{C} \mathrm{NMR}\left(100 \mathrm{MHz}, \mathrm{CDCl}_{3}\right)$ ס: 173.6, 57.3, 40.2, 33.6, 30.3, 25.4, 24.4, 23.7.

IR (neat, ATR): 2933, 2853, 1657,1445, 1423,1674, 1372, 1313, 1272.

HRMS (ESI+): Calcd. for [C $\left.{ }_{8} \mathrm{H}_{13} \mathrm{NO}+\mathrm{H}\right]^{+}:$140.1070, found: 140.1070 .

\section{(士)-Coniceine (16)}

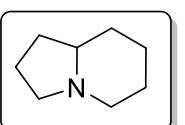

Hexahydroindolizin-3(2H)-one $15(7.0 \mathrm{mg}, 0.05 \mathrm{mmol})$ is dissolved in $0.5 \mathrm{~mL}$ of $\mathrm{Et}_{2} \mathrm{O}$ under an argon atmosphere and $\mathrm{LiAlH}_{4}(2.3 \mathrm{mg}, 0.06 \mathrm{mmol})$ is added at $0^{\circ} \mathrm{C}$. The temperature of the reaction mixture is allowed to raise to room temperature and to stir at this temperature for 8 hours. Then, the reaction is cooled to $0^{\circ} \mathrm{C}$, quenched sequentially with $10 \mu \mathrm{L} \mathrm{H} \mathrm{H}_{2} \mathrm{O}, 10 \mu \mathrm{L} 10 \% \mathrm{NaOH}_{(\text {aq) }}, 30 \mu \mathrm{L} \mathrm{H} \mathrm{H}_{2} \mathrm{O}$ and dried over anhydrous $\mathrm{MgSO}_{4}$. The mixture is 
filtered through a pad of celite, while eluting with $\mathrm{Et}_{2} \mathrm{O}$ and concentrated under vacuum to produce the title compound as a light yellow oil: $6.3 \mathrm{mg}, 100 \%$. The NMR spectra matched those previously described in literature. ${ }^{5}$

${ }^{1} \mathbf{H}$ NMR (400 MHz, $\left.\mathrm{CDCl}_{3}\right) \delta: 3.13-3.06(\mathrm{~m}, 1 \mathrm{H}), 3.04(\mathrm{td}, J=8.7 \mathrm{~Hz}, J=2.0 \mathrm{~Hz}, 1 \mathrm{H}), 2.05$ (q, $J=9.0 \mathrm{~Hz}, 1 \mathrm{H}), 1.95(\mathrm{dt}, J=11.4 \mathrm{~Hz}, J=3.3 \mathrm{~Hz}, 1 \mathrm{H}), 1.84-1.74(\mathrm{~m}, 3 \mathrm{H}), 1.73-1.68(\mathrm{~m}$, $2 \mathrm{H}), 1.67-1.60(\mathrm{~m}, 2 \mathrm{H}), 1.59-1.51(\mathrm{~m}, 1 \mathrm{H}), 1.42-1.32(\mathrm{~m}, 1 \mathrm{H}), 1.26-1.16(\mathrm{~m}, 2 \mathrm{H})$.

${ }^{13} \mathrm{C} \mathrm{NMR}\left(100 \mathrm{MHz} \mathrm{CDCl}_{3}\right) \delta: 64.4,54.3,53.1,31.1,30.5,25.6,24.6,20.7$.

IR (neat, ATR): 2952, 2920, 1461, 1454, 1320, 1255, 1096.

HRMS (ESI+): Calcd. for $\left[\mathrm{C}_{8} \mathrm{H}_{15} \mathrm{~N}+\mathrm{H}\right]^{+}:$126.1277, found: 126.1277 .

\section{1-(3-oxobutyl)piperidine-2,6-dione (18)}

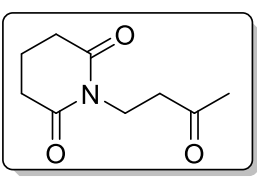

Similar to a procedure by Rasapalli and coworkers. ${ }^{1}$ To a solution of glutarimide 17 (623 mg, $5.50 \mathrm{mmol})$ in AcOEt $(6 \mathrm{~mL})$ is added EtONa (18.7

$\mathrm{mg}, 0.28 \mathrm{mmol}$ ) under argon atmosphere. After 15 minutes stirring at room temperature, MVK $12(506 \mu \mathrm{L}, 6.06 \mathrm{mmol})$ is added and the resulting mixture is refluxed at $77^{\circ} \mathrm{C}$ for 16 hours. Then, the reaction is cooled to room temperature and water is added. The aqueous phase is extracted with AcOEt $(3 \times 5 \mathrm{~mL})$, dried over anhydrous $\mathrm{MgSO}_{4}$ and concentrated under reduced pressure to afford the title compound as a beige solid: $1.01 \mathrm{~g}$, $100 \%$.

${ }^{1} \mathrm{H}$ NMR $\left(400 \mathrm{MHz}_{\mathrm{CDCl}}\right.$ ) $): 4.03(\mathrm{t}, \mathrm{J}=7.2 \mathrm{~Hz}, 2 \mathrm{H}), 2.67-2.62(\mathrm{~m}, 6 \mathrm{H}), 2.16(\mathrm{~s}, 3 \mathrm{H}), 1.97-$ $1.88(\mathrm{~m}, 2 \mathrm{H})$.

${ }^{13} \mathrm{C}$ NMR (100 MHz, $\left.\mathrm{CDCl}_{3}\right)$ ס: 206.7, 172.4, 41.5, 34.9, 32.7, 30.0, 17.0.

M.P.: $38-40^{\circ} \mathrm{C}$.

IR (neat, ATR): 2978, 1712, 1674, 1354, 1168, 1138.

HRMS (ESI+): Calcd. for [ $\left.\mathrm{C}_{9} \mathrm{H}_{13} \mathrm{NO}_{3}+\mathrm{H}\right]^{+}:$184.0968, found 184.0968.

\section{3,4,8,9-tetrahydro-2H-quinolizine-2,6(7H)-dione (19)}

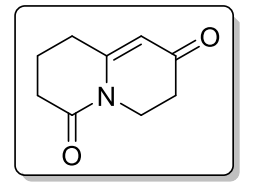

To a stirred solution of 1-(3-oxobutyl)piperidine-2,6-dione 18 (700 mg, 3.82 mmol) or 1-(2-(2-methyl-1,3-dioxolan-2-yl)ethyl)piperidine-2,6-dione 24 (868 mg, $3.82 \mathrm{mmol})$ in toluene $(20 \mathrm{~mL}), \mathrm{TfOH}(354 \mu \mathrm{L}, 4.01 \mathrm{mmol})$ is added, and the mixture is heated at $90^{\circ} \mathrm{C}$ for $16 \mathrm{~h}$. The reaction is quenched with $\mathrm{NaHCO}_{3}(385$ 
$\mathrm{mg}, 4.58 \mathrm{mmol})$ and $10 \mathrm{~mL}$ of water. The organic phase is extracted with DCM (4 $\times 5 \mathrm{~mL})$, dried over anhydrous $\mathrm{MgSO}_{4}$ and concentrated under reduced pressure. Purification by flash column chromatography (98:2 DCM:MeOH) affords the title compound as an orange solid: 623 mg, $99 \%$. The spectroscopic data are identical to those previously described. ${ }^{6}$

${ }^{1} \mathrm{H}$ NMR $\left(400 \mathrm{MHz}, \mathrm{CDCl}_{3}\right) \delta: 5.25(\mathrm{~s}, 1 \mathrm{H}), 4.14(\mathrm{t}, J=7.1 \mathrm{~Hz}, 2 \mathrm{H}), 2.64(\mathrm{t}, J=6.2 \mathrm{~Hz}, 4 \mathrm{H})$, $2.51(\mathrm{t}, J=7.1 \mathrm{~Hz}, 2 \mathrm{H}), 1.99-1.91(\mathrm{~m}, 2 \mathrm{H})$.

${ }^{13} \mathrm{C}$ NMR $\left(100 \mathrm{MHz}, \mathrm{CDCl}_{3}\right) \delta:$ 193.4, 169.0, 156.3, 106.8, 40.4, 35.5, 33.0, 29.8, 19.0.

M.P.: $96^{\circ} \mathrm{C}$.

IR (neat, ATR): 3060, 2960, 1695, 1660, 1650, 1590.

HRMS (ESI+): Calcd. for [ $\left.\mathrm{C}_{9} \mathrm{H}_{11} \mathrm{NO}_{2}+\mathrm{H}\right]^{+}:$166.0863, found: 166.0863 .

\section{Octahydro-4H-quinolizin-4-one (20)}

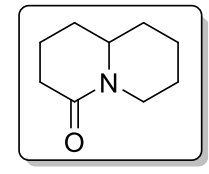

A mixture containing $500 \mathrm{mg}(3.03 \mathrm{mmol})$ of 3,4,8,9-tetrahydro-2H-quinolizine2,6(7H)-dione $19,322 \mathrm{mg}(0.30 \mathrm{mmol})$ of $10 \% \mathrm{Pd} / \mathrm{C}$ and $20 \mathrm{~mL}$ of $\mathrm{HCl}(1.0 \mathrm{M}$ in $\mathrm{EtOH}$ ) is subjected to a $\mathrm{H}_{2}$ atmosphere ( $1 \mathrm{~atm}$ ) for $4 \mathrm{~h}$. Then, the reaction mixture is filtered through a pad of celite and the solvent is removed under reduced pressure. The residue is purified by flash column chromatography (AcOEt) to afford the title compound as a transparent oil: $338 \mathrm{mg}, 73 \%$.

Wolff-Kishner reduction protocol to convert 21 to 20: Similar to a procedure by Rotier and coworkers. ${ }^{7}$ Hexahydro-2H-quinolizine-2,6(1H)-dione 21 (34 mg, $0.20 \mathrm{mmol}$ ) and $\mathrm{H}_{2} \mathrm{NNH}_{2} \cdot \mathrm{H}_{2} \mathrm{O}$ $55 \%$ (72 $\mu \mathrm{L}, 0.81 \mathrm{mmol})$ were added to a solution containing sodium (14 mg, $0.61 \mathrm{mmol})$ in $2.0 \mathrm{~mL}$ of ethylene glycol. Then, the mixture is refluxed at $140^{\circ} \mathrm{C}$ for $4 \mathrm{~h}$ and left to cool to room temperature. Then, DCM $(5 \mathrm{~mL})$ is added and the organic phase is washed with $1 \mathrm{M}$ aqueous solution of $\mathrm{NaOH}(5 \mathrm{~mL})$, dried over anhydrous $\mathrm{MgSO}_{4}$ and purified by flash column chromatography (AcOEt) to afford the title compound as a transparent oil: $30 \mathrm{mg}, 80 \%$.

In both of the previous cases, the spectroscopic data are consistent with the literature. ${ }^{8}$

${ }^{1} \mathrm{H}$ NMR $\left(400 \mathrm{MHz}, \mathrm{CDCl}_{3}\right) \delta: 4.81-4.74(\mathrm{~m}, 1 \mathrm{H}), 3.26-3.18(\mathrm{~m}, 1 \mathrm{H}), 2.45-2.26(\mathrm{~m}, 3 \mathrm{H})$, $1.98-1.93(\mathrm{~m}, 1 \mathrm{H}), 1.87-1.77(\mathrm{~m}, 2 \mathrm{H}), 1.73-1.65(\mathrm{~m}, 3 \mathrm{H}), 1.53-1.18(\mathrm{~m}, 4 \mathrm{H})$.

${ }^{13} \mathrm{C}$ NMR $\left(100 \mathrm{MHz}, \mathrm{CDCl}_{3}\right) \delta: 169.3,56.8,42.3,34.0,33.0,30.4,25.3,24.4,19.1$. 
IR (neat, ATR): 3010, 2945, 2860, 1620, 1479, 1452, 1283.

HRMS (ESI+): Calcd. for [ $\left.\mathrm{C}_{9} \mathrm{H}_{15} \mathrm{NO}+\mathrm{H}\right]^{+}:$154.1226, found: 154.1231.

\section{Hexahydro-2H-quinolizine-2,6(1H)-dione (21)}

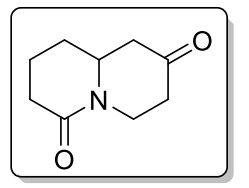

A mixture containing $110 \mathrm{mg}(0.67 \mathrm{mmol})$ of 3,4,8,9-tetrahydro-2H-quinolizine2,6(7H)-dione $19,71 \mathrm{mg}(0.07 \mathrm{mmol})$ of $10 \% \mathrm{Pd} / \mathrm{C}$ and $5 \mathrm{~mL}$ of AcOEt was subjected to a $\mathrm{H}_{2}$ atmosphere $(1 \mathrm{~atm})$ for $8 \mathrm{~h}$. Then, the reaction mixture is filtered through a pad of celite and the solvent is removed under reduced pressure. The crude reaction mixture is purified by flash column chromatography (AcOEt) to afford the title compound as a transparent oil: $70 \mathrm{mg}, 63 \%$. The spectroscopic data are consistent with those in the literature. ${ }^{9}$

${ }^{1} \mathrm{H}$ NMR $\left(400 \mathrm{MHz}, \mathrm{CDCl}_{3}\right) \delta: 4.88(\mathrm{ddd}, J=13.4 \mathrm{~Hz}, J=5.9 \mathrm{~Hz}, J=3.9 \mathrm{~Hz}, 1 \mathrm{H}), 3.73-3.64$ (m, 1H), 2.89 (ddd, $J=13.4 \mathrm{~Hz}, J=10.3 \mathrm{~Hz}, J=5.4 \mathrm{~Hz}, 1 \mathrm{H}$ ), $2.50-2.38(\mathrm{~m}, 6 \mathrm{H}), 2.14-2.03$ $(\mathrm{m}, 1 \mathrm{H}), 1.94-1.83(\mathrm{~m}, 1 \mathrm{H}), 1.82-1.72(\mathrm{~m}, 1 \mathrm{H}), 1.66-1.55(\mathrm{~m}, 1 \mathrm{H})$.

${ }^{13} \mathrm{C}$ NMR $\left(100 \mathrm{MHz}, \mathrm{CDCl}_{3}\right)$ ס: 206.9, 169.5, 54.9, 48.1, 40.9, 40.5, 32.6, 29.6, 18.8.

IR (neat, ATR): 2951, 1712, 1616, 1469, 1446, 1334.

HRMS (ESI+): Calcd. for [ $\left.\mathrm{C}_{9} \mathrm{H}_{13} \mathrm{NO}_{2}+\mathrm{H}\right]^{+}:$168.1019, found: 168.1017 .

\section{(士)-Quinolizidine (22)}

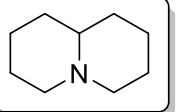

Amide Hexahydroindolizin-3(2H)-one $20(200 \mathrm{mg}, 1.30 \mathrm{mmol})$ is dissolved in 10 $\mathrm{mL}$ of $\mathrm{Et}_{2} \mathrm{O}$ under an argon atmosphere, and $\mathrm{LiAlH}_{4}(248 \mathrm{mg}, 6.52 \mathrm{mmol})$ is added portionwise at $0^{\circ} \mathrm{C}$. The reaction temperature is allowed to raise to room temperature and to stir at this temperature for 8 hours. Then, the reaction is cooled to $0^{\circ} \mathrm{C}$, quenched sequentially with $250 \mu \mathrm{L} \mathrm{H} \mathrm{H}_{2} \mathrm{O}, 250 \mu \mathrm{L} 10 \% \mathrm{NaOH}, 750 \mu \mathrm{L} \mathrm{H} \mathrm{H}_{2} \mathrm{O}$ and dried with anhydrous $\mathrm{MgSO}_{4}$. The mixture is filtered through a pad of celite, while eluting with $\mathrm{Et}_{2} \mathrm{O}$ and concentrated under reduced pressure to produce the title compound as a light yellow oil: 168 $\mathrm{mg}, 93 \%$.

${ }^{1} \mathrm{H}$ NMR $\left(400 \mathrm{MHz}, \mathrm{CDCl}_{3}\right) \delta: 2.99-2.89(\mathrm{~m}, 3 \mathrm{H}), 2.13(\mathrm{td}, J=11.6 \mathrm{~Hz}, J=3.9 \mathrm{~Hz}, 2 \mathrm{H}), 1.78$ $-1.73(\mathrm{~m}, 2 \mathrm{H}), 1.69(\mathrm{dt}, J=11.6 \mathrm{~Hz}, J=3.9 \mathrm{~Hz}, 2 \mathrm{H}), 1.62-1.54(\mathrm{~m}, 3 \mathrm{H}), 1.39-1.16(\mathrm{~m}, 5 \mathrm{H})$. ${ }^{13} \mathrm{C}$ NMR $\left(100 \mathrm{MHz}, \mathrm{CDCl}_{3}\right) \delta: 63.5,56.5,32.7,25.2,24.1$.

M.P. (as a picrate salt): $191^{\circ} \mathrm{C}$. 
IR (neat, ATR): 2931, 2854, 1450, 1242, 1226, 1165, 1099, 1029.

HRMS (ESI+): Calcd. for [ $\left.\mathrm{C}_{9} \mathrm{H}_{17} \mathrm{~N}+\mathrm{H}\right]^{+}:$140.1434, found: 140.1438 .

(ESI-, as a picrate salt): Calcd. for $\left[\mathrm{C}_{6} \mathrm{H}_{3} \mathrm{~N}_{3} \mathrm{O}_{7}-\mathrm{H}\right]: 227.9898$, found: 227.9907.

\section{1-(2-(2-methyl-1,3-dioxolan-2-yl)ethyl)pyrrolidine-2,5-dione (23)}

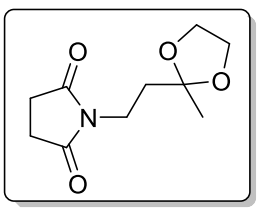

A stirred solution of 1-(3-oxobutyl)pyrrolidine-2,5-dione 13 (727 mg, 4.30 mmol), pTSA $\cdot \mathrm{H}_{2} \mathrm{O}$ (82 $\left.\mathrm{mg}, 0.43 \mathrm{mmol}\right)$, ethylene glycol $(482 \mu \mathrm{L}, 8.6 \mathrm{mmol})$ and toluene $(5 \mathrm{~mL})$ is refluxed $\left(110{ }^{\circ} \mathrm{C}\right)$ for 24 hours using a Dean-Stark apparatus. Then, the reaction is quenched with $1 \mathrm{~mL}$ of saturated aqueous solution of $\mathrm{NaHCO}_{3}$ and extracted with AcOEt $(3 \times 5 \mathrm{~mL})$, dried over anhydrous $\mathrm{MgSO}_{4}$ and purified by flash column chromatography (1:1 Hexanes:AcOEt) to afford the title compound as a white solid: $682 \mathrm{mg}, 74 \%$,.

${ }^{1} \mathrm{H}$ NMR $\left(500 \mathrm{MHz}, \mathrm{CDCl}_{3}\right) \delta: 3.92(\mathrm{~s}, 4 \mathrm{H}), 3.63(\mathrm{t}, J=7.3 \mathrm{~Hz}, 2 \mathrm{H}), 2.66(\mathrm{~s}, 4 \mathrm{H}), 1.95(\mathrm{t}, J=$ $7.3 \mathrm{~Hz}, 2 \mathrm{H}), 1.33(\mathrm{~s}, 3 \mathrm{H})$.

${ }^{13} \mathrm{C}$ NMR $\left(125 \mathrm{MHz}, \mathrm{CDCl}_{3}\right) \delta: 177.2,108.7,64.6,35.4,34.3,28.2,23.7$.

M.P.: $81^{\circ} \mathrm{C}$.

IR (neat, ATR): 2995, 2963, 2888, 1694, 1406, 1382, 1339, 1179, 1149, 1057.

HRMS (ESI+): Calcd. for [ $\left.\mathrm{C}_{10} \mathrm{H}_{15} \mathrm{NO}_{4+}+\mathrm{H}\right]^{+}: 214.1074$, found: 214.1073 .

\section{1-(2-(2-methyl-1,3-dioxolan-2-yl)ethyl)piperidine-2,6-dione (24)}

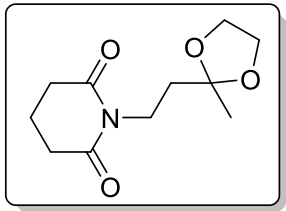

A stirred solution of 1-(3-oxobutyl)piperidine-2,6-dione 18 (990 mg, 5.40 mmol), pTSA. $\mathrm{H}_{2} \mathrm{O}(205 \mathrm{mg}, 1.08 \mathrm{mmol})$, ethylene glycol $(452 \mu \mathrm{L}, 8.10$ $\mathrm{mmol})$ and toluene $(5.0 \mathrm{~mL})$ is refluxed $\left(110^{\circ} \mathrm{C}\right)$ for 24 hours using a DeanStark apparatus. Then, the reaction is quenched with $3 \mathrm{~mL}$ of saturated aqueous solution of $\mathrm{NaHCO}_{3}$, extracted with AcOEt $(3 \times 5 \mathrm{~mL})$, dried over anhydrous $\mathrm{MgSO}_{4}$ and purified by flash column chromatography (9:1 DCM:AcOEt) to afford the title compound as an yellow oil: $1.17 \mathrm{~g}, 95 \%$.

${ }^{1} \mathrm{H}$ NMR $\left(400 \mathrm{MHz}, \mathrm{CDCl}_{3}\right)$ ס: $3.93(\mathrm{~s}, 4 \mathrm{H}), 3.91-3.87(\mathrm{~m}, 2 \mathrm{H}), 2.63(\mathrm{t}, J=6.5 \mathrm{~Hz}, 4 \mathrm{H}), 1.95-$ $1.89(\mathrm{~m}, 2 \mathrm{H}), 1.88-1.83(\mathrm{~m}, 2 \mathrm{H}), 1.37(\mathrm{~s}, 3 \mathrm{H})$.

${ }^{13} \mathrm{C}$ NMR $\left(100 \mathrm{MHz}, \mathrm{CDCl}_{3}\right) \delta: 172.4,108.9,64.5,36.0,35.3,32.9,23.6,17.1$.

IR (neat, ATR): 2960, 2885, 1720, 1666. 1140, 1350. 
HRMS (ESI+): Calcd. for [ $\left.\mathrm{C}_{11} \mathrm{H}_{17} \mathrm{NO}_{4+} \mathrm{H}\right]^{+}:$228.1230, found: 228.1234

1-(hex-5-en-1-yl)pyrrolidine-2,5-dione (26)

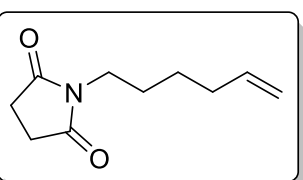

Following a reported procedure by Martin and coworkers. ${ }^{10}$ To a solution of succinimide 11 (164 mg, $1.65 \mathrm{mmol}$ ), $\mathrm{PPh}_{3}(564 \mathrm{mg}, 2.15 \mathrm{mmol}$ ) and hex5-en-1-ol $25(238 \mu \mathrm{L}, 1.99 \mathrm{mmol})$ in THF $(10.0 \mathrm{~mL})$, at $0^{\circ} \mathrm{C}$, is added diisopropyl azodicarboxylate $(424 \mu \mathrm{L}, 2.15 \mathrm{mmol})$ dropwise. The reaction is stirred at room temperature for 24 hours. Then, the reaction mixture is concentrated under reduced pressure. The residue is purified by flash column chromatography (DCM) to afford the title compound as yellow oil: $261 \mathrm{mg}, 87 \%$. The spectroscopic data are consistent with those in the literature. ${ }^{10}$

${ }^{1} \mathrm{H}$ NMR $\left(400 \mathrm{MHz}, \mathrm{CDCl}_{3}\right) \delta: 5.83-5.71(\mathrm{~m}, 1 \mathrm{H}), 5.04-4.91(\mathrm{~m}, 2 \mathrm{H}), 3.50(\mathrm{t}, J=7.4 \mathrm{~Hz}, 2 \mathrm{H})$, $2.69(\mathrm{~s}, 4 \mathrm{H}), 2.07(\mathrm{q}, J=7.1 \mathrm{~Hz}, 2 \mathrm{H}), 1.63-1.52(\mathrm{~m}, 2 \mathrm{H}), 1.44-1.32(\mathrm{~m}, 2 \mathrm{H})$.

${ }^{13} \mathrm{C}$ NMR $\left(100 \mathrm{MHz}, \mathrm{CDCl}_{3}\right) \delta: 177.3,138.2,114.9,38.7,33.2,28.1,27.1,26.0$.

IR (neat, ATR): 3020, 2939, 2862, 1774, 1693, 1639, 1400.

HRMS (ESI+): Calcd. for [ $\left.\mathrm{C}_{10} \mathrm{H}_{15} \mathrm{NO}_{2}+\mathrm{H}\right]^{+}:$182.1176, found: 182.1182.

\section{5-(2,5-dioxopyrrolidin-1-yl)pentanal (27)}

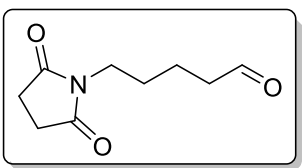

1-(hex-5-en-1-yl)pyrrolidine-2,5-dione 26 (200 mg, $1.10 \mathrm{mmol})$ is dissolved in $12 \mathrm{~mL}$ of a $7: 1$ mixture $\mathrm{DCM}: \mathrm{MeOH}$ and cooled to $-78^{\circ} \mathrm{C}$. Ozone is bubbled to the solution until a light blue color appeared (in approx. 10 minutes). Then, the solution is purged with oxygen and nitrogen until the excess of ozone was dissipated and the blue color diminished. Then, $\mathrm{PPh}_{3}(347 \mathrm{mg}, 1.325 \mathrm{mmol})$ is added and the reaction is allowed to slowly warm up from $-78{ }^{\circ} \mathrm{C}$ to room temperature over 2 hours. Finally, the solvents are removed under reduced ressure and the reaction mixture is purified by flash column chromatography (DCM) to afford the title compound as a colorless oil: $186 \mathrm{mg}, 92 \%$ yield.

${ }^{1} \mathrm{H}$ NMR $\left(400 \mathrm{MHz}, \mathrm{CDCl}_{3}\right) \delta: 9.72(\mathrm{t}, J=1.2 \mathrm{~Hz}, 1 \mathrm{H}), 3.49(\mathrm{t}, J=6.4 \mathrm{~Hz}, 2 \mathrm{H}), 2.68(\mathrm{~s}, 4 \mathrm{H})$, $2.46(\mathrm{t}, J=6.4 \mathrm{~Hz}, 2 \mathrm{H}), 1.61-1.56(\mathrm{~m}, 4 \mathrm{H})$.

${ }^{13} \mathrm{C}$ NMR $\left(100 \mathrm{MHz}, \mathrm{CDCl}_{3}\right) \delta: 201.8,177.2,43.1,38.2,28.1,27.0,19.1$.

IR (neat, ATR): 2943, 2252, 1693, 1404, 1153.

HRMS (ESI+): Calcd. for [ $\left.\mathrm{C}_{9} \mathrm{H}_{13} \mathrm{NO}_{3}+\mathrm{H}\right]^{+}:$184.0968, found: 184.0968 . 


\section{1-(4-(1,3-dioxolan-2-yl)butyl)pyrrolidine-2,5-dione (28)}

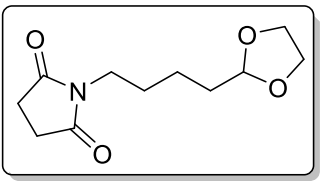

A stirred solution of 5-(2,5-dioxopyrrolidin-1-yl)pentanal 27 (150 mg, 0.82 mmol), pTSA $\mathrm{H}_{2} \mathrm{O}(16 \mathrm{mg}, 0.082 \mathrm{mmol})$, ethylene glycol $(92 \mu \mathrm{L}, 1.64$ $\mathrm{mmol})$ and toluene $(10 \mathrm{~mL})$ is refluxed for 24 hours using a Dean-Stark apparatus. The reaction is quenched with $1 \mathrm{~mL}$ of saturated aqueous solution of $\mathrm{NaHCO}_{3}$, extracted with AcOEt $(3 \times 5 \mathrm{~mL})$, dried over anhydrous $\mathrm{MgSO}_{4}$ and purified by flash column chromatography (DCM) to afford the title product as an yellow oil: $175 \mathrm{mg}, 94 \%$.

${ }^{1} \mathrm{H}$ NMR $\left(400 \mathrm{MHz}, \mathrm{CDCl}_{3}\right) \delta: 4.83(\mathrm{t}, J=4.7 \mathrm{~Hz}, 1 \mathrm{H}), 3.99-3.89(\mathrm{~m}, 2 \mathrm{H}), 3.88-3.81(\mathrm{~m}, 2 \mathrm{H})$, $3.51(\mathrm{t}, J=7.4 \mathrm{~Hz}, 2 \mathrm{H}), 2.69(\mathrm{~s}, 4 \mathrm{H}), 1.70-1.58(\mathrm{~m}, 4 \mathrm{H}), 1.46-1.37(\mathrm{~m}, 2 \mathrm{H})$.

${ }^{13} \mathrm{C}$ NMR $\left(100 \mathrm{MHz}, \mathrm{CDCl}_{3}\right)$ ס: 177.2, 104.2, 64.8, 38.7, 33.3, 28.1, 27.6, 21.3.

IR (neat, ATR): 2935, 2615, 1766, 1708, 1627, 1392, 1253, 1006.

HRMS (ESI+): Calcd. for $\left[\mathrm{C}_{11} \mathrm{H}_{17} \mathrm{NO}_{4+} \mathrm{H}\right]^{+}: 228.1230$, found: 228.1231

\section{( \pm )-Tashiromine (30)}

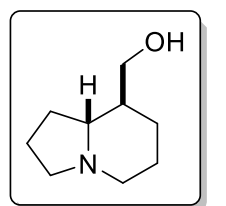

To a stirred solution of 1-(4-(1,3-dioxolan-2-yl)butyl)pyrrolidine-2,5-dione 28 (14 $\mathrm{mg}, 0.06 \mathrm{mmol})$ in toluene $(1 \mathrm{~mL})$, is added $\mathrm{TfOH}(6.0 \mu \mathrm{L}, 0.06 \mathrm{mmol})$ and the mixture is heated at $90^{\circ} \mathrm{C}$ for $16 \mathrm{~h}$. The reaction is quenched with $\mathrm{NaHCO}_{3}(6.2$ $\mathrm{mg}, 0.07 \mathrm{mmol}$ ) and $5 \mathrm{~mL}$ of water. The aqueous phase is extracted with DCM (3 $x 2 \mathrm{~mL}$ ), dried over anhydrous $\mathrm{MgSO}_{4}$ and concentrated under reduced pressure. The residue is dissolved in $\mathrm{Et}_{2} \mathrm{O}(5 \mathrm{~mL})$ under argon atmosphere, then $\mathrm{LiAlH}_{4}(11.7 \mathrm{mg}, 0.31 \mathrm{mmol})$ is added at $0^{\circ} \mathrm{C}$ and the reaction mixture is stirred for 8 hours. The reaction is sequentially quenched with $12 \mu \mathrm{L} \mathrm{H} \mathrm{H}_{2} \mathrm{O}, 12 \mu \mathrm{L} 10 \% \mathrm{NaOH}_{(\mathrm{aq})}, 36 \mu \mathrm{L} \mathrm{H}_{2} \mathrm{O}$ and dried over anhydrous $\mathrm{MgSO}_{4}$. The mixture is filtered through a pad of celite, while eluting with $\mathrm{Et}_{2} \mathrm{O}$, concentrated under reduced pressure and purified by flash column chromatography (7:3 DCM:MeOH) to afford the title compound as a light yellow oil: $5.2 \mathrm{mg}, 54 \%$. The spectroscopic data are consistent with those in the literature. ${ }^{11}$

${ }^{1} \mathrm{H}$ NMR $\left(400 \mathrm{MHz}, \mathrm{CDCl}_{3}\right) \delta: 3.65(\mathrm{dd}, J=10.8 \mathrm{~Hz}, J=4.7 \mathrm{~Hz}, 1 \mathrm{H}), 3.50(\mathrm{dd}, J=10.8 \mathrm{~Hz}, J=$ $6.4 \mathrm{~Hz}, 1 \mathrm{H}), 3.14-3.04(\mathrm{~m}, 2 \mathrm{H}), 2.09(\mathrm{q}, J=9.1 \mathrm{~Hz}, 1 \mathrm{H}), 1.91-1.58(\mathrm{~m}, 9 \mathrm{H}), 1.56-1.46(\mathrm{~m}$, 2H), 1.06 (tdd, $J=12.7 \mathrm{~Hz}, J=11.6 \mathrm{~Hz}, J=4.7 \mathrm{~Hz}, 1 \mathrm{H}$ ).

${ }^{13} \mathrm{C}$ NMR $\left(100 \mathrm{MHz}, \mathrm{CDCl}_{3}\right)$ ס: 66.3, 65.6, 54.1, 52.6, 44.6, 29.0, 27.6, 25.1, 20.7.

IR (neat, ATR): 3340, 2927, 2792, 1728, 1658, 1462, 1442, 1165, 1087, 1037. 
HRMS (ESI+): Calcd. for [ $\left.\mathrm{C}_{9} \mathrm{H}_{17} \mathrm{NO}+\mathrm{H}\right]^{+}:$156.1383, found: 156.1389 .

\section{1-(hex-5-en-1-yl)piperidine-2,6-dione (32)}

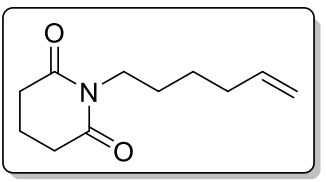

Following a reported procedure by Martin and coworkers. ${ }^{10}$ To a solution of glutarimide 17 (188 mg, $1.66 \mathrm{mmol}$ ), $\mathrm{PPh}_{3}(567 \mathrm{mg}, 2.16 \mathrm{mmol}$ ), and hex-5-en-1-ol $25(240 \mu \mathrm{L}, 1.99 \mathrm{mmol})$ in THF $(10.0 \mathrm{~mL})$ at $0^{\circ} \mathrm{C}$ is added diisopropyl azodicarboxylate $(425 \mu \mathrm{L}, 2.16 \mathrm{mmol})$ dropwise and the reaction is stirred at room temperature for 28 hours. Then, the reaction mixture is concentrated under reduced pressure.

The residue is purified by flash column chromatography (DCM) to afford the title compound as a yellow oil: $297 \mathrm{mg}, 92 \%$. The spectroscopic data are consistent with those in the literature. ${ }^{10}$

${ }^{1} \mathrm{H}$ NMR $\left(400 \mathrm{MHz}, \mathrm{CDCl}_{3}\right) \delta: 5.78(\mathrm{ddt}, J=16.9 \mathrm{~Hz}, J=10.2 \mathrm{~Hz}, J=6.6 \mathrm{~Hz}, 1 \mathrm{H}), 5.03-4.91$ (m, 2H), 3.75 (d, J=7.5 Hz, 2H), $2.64(\mathrm{t}, J=6.6 \mathrm{~Hz}, 4 \mathrm{H}), 2.06(\mathrm{q}, J=7.1 \mathrm{~Hz}, 2 \mathrm{H}), 1.96-1.89$ (m, 2H), $1.55-1.45(\mathrm{~m}, 2 \mathrm{H}), 1.43-1.34(\mathrm{~m}, 2 \mathrm{H})$.

${ }^{13} \mathrm{C}$ NMR $\left(100 \mathrm{MHz}, \mathrm{CDCl}_{3}\right) \delta: 172.5,138.5,114.6,39.4,33.4,32.9,27.5,26.2,17.2$.

IR (neat, ATR): 3062, 2985, 2939, 1735, 1674, 1442, 1373, 1238, 1091, 1045.

HRMS (ESI+): Calcd. for [ $\left.\mathrm{C}_{11} \mathrm{H}_{17} \mathrm{NO}_{2}+\mathrm{H}\right]^{+}:$196.1332, found: 196.1328.

\section{5-(2,6-dioxopiperidin-1-yl)pentanal (33)}

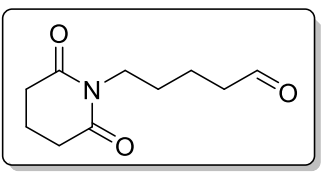

1-(hex-5-en-1-yl)piperidine-2,6-dione 32 ( $85 \mathrm{mg}, 0.435 \mathrm{mmol})$ is dissolved in $8 \mathrm{~mL}$ of a $7: 1$ mixture $\mathrm{DCM}: \mathrm{MeOH}$ and cooled to $-78^{\circ} \mathrm{C}$. Ozone is bubbled to the solution until a light blue color appeared (approx. In 10 minutes). Then, the solution is purged with oxygen and nitrogen until the excess ozone is dissipated and the blue color fades. Then, $\mathrm{PPh}_{3}(137 \mathrm{mg}, 0.522 \mathrm{mmol})$ is added, and the reaction is allowed to slowly warm up from $-78^{\circ} \mathrm{C}$ to room temperature over 2 hours. Finally, the solvents are removed under reduced pressure and the residue is purified by flash column chromatography (DCM) to afford the title compound as a colorless oil: $75 \mathrm{mg}, 87 \%$ yield.

${ }^{1} \mathrm{H}$ NMR $\left(400 \mathrm{MHz}, \mathrm{CDCl}_{3}\right) \delta: 9.72(\mathrm{~s}, 1 \mathrm{H}), 3.74(\mathrm{t}, J=7.2 \mathrm{~Hz}, 2 \mathrm{H}), 2.62(\mathrm{t}, J=6.6 \mathrm{~Hz}, 4 \mathrm{H})$, $2.44(\mathrm{dt}, J=7.2 \mathrm{~Hz}, J=1.0 \mathrm{~Hz}, 2 \mathrm{H}), 1.91(\mathrm{p}, J=6.6 \mathrm{~Hz}, 2 \mathrm{H}), 1.63-1.47(\mathrm{~m}, 4 \mathrm{H})$.

${ }^{13} \mathrm{C}$ NMR $\left(100 \mathrm{MHz}, \mathrm{CDCl}_{3}\right)$ ס: 202.2, 172.5, 43.3, 38.9, 32.8, 27.3, 19.2, 17.1.

IR (neat, ATR): 1728, 1670, 1045.

HRMS (ESI+): Calcd. for [ $\left.\mathrm{C}_{10} \mathrm{H}_{15} \mathrm{NO}_{3}+\mathrm{H}\right]^{+}:$198.1125, found: 198.1117. 


\section{1-(4-(1,3-dioxolan-2-yl)butyl)piperidine-2,6-dione (34)}

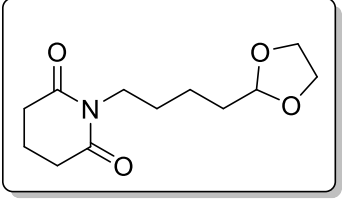

A stirred solution of 5-(2,6-dioxopiperidin-1-yl)pentanal $\mathbf{3 3}$ (60 mg, 0.30 $\mathrm{mmol}), \mathrm{pTSA} \cdot \mathrm{H}_{2} \mathrm{O}(6 \mathrm{mg}, 0.03 \mathrm{mmol})$, ethylene glycol $(34 \mu \mathrm{L}, 0.6 \mathrm{mmol})$ and toluene $(10 \mathrm{~mL})$ is refluxed $\left(110^{\circ} \mathrm{C}\right)$ for 24 hours using a Dean-Stark apparatus. The reaction is quenched with $1 \mathrm{~mL}$ of saturated aqueous solution of $\mathrm{NaHCO}_{3}$, extracted with AcOEt $\left(3 \times 5 \mathrm{~mL}\right.$ ), dried over anhydrous $\mathrm{MgSO}_{4}$ and purified by flash column chromatography (8:2 DCM:AcOEt) to afford the title compound as an yellow oil: $67 \mathrm{mg}, 91 \%$.

${ }^{1} \mathrm{H}$ NMR $\left(400 \mathrm{MHz}, \mathrm{CDCl}_{3}\right) \delta: 4.82(\mathrm{t}, J=4.8 \mathrm{~Hz}, 1 \mathrm{H}), 3.96-3.89(\mathrm{~m}, 2 \mathrm{H}), 3.86-3.80(\mathrm{~m}, 2 \mathrm{H})$, $3.74(\mathrm{~d}, J=7.5 \mathrm{~Hz}, 2 \mathrm{H}), 2.62(\mathrm{t}, J=6.6 \mathrm{~Hz}, 4 \mathrm{H}), 1.94-1.87(\mathrm{~m}, 2 \mathrm{H}), 1.69-1.63(\mathrm{~m}, 2 \mathrm{H})$, $1.58-1.49(\mathrm{~m}, 2 \mathrm{H}), 1.45-1.36(\mathrm{~m}, 2 \mathrm{H})$.

${ }^{13} \mathrm{C} \mathrm{NMR}\left(100 \mathrm{MHz}, \mathrm{CDCl}_{3}\right) \delta: 172.4,104.3,64.8,39.4,33.4,32.8,27.8,21.4,17.1$.

IR (neat, ATR): 2966, 2885, 1720, 1666, 1442, 1354, 1114, 1049.

HRMS (ESI+): Calcd. for $\left[\mathrm{C}_{12} \mathrm{H}_{19} \mathrm{NO}_{4+} \mathrm{Na}\right]^{+}: 264.1206$, found: 264.1208.

\section{( \pm )-Epilupinine (36)}

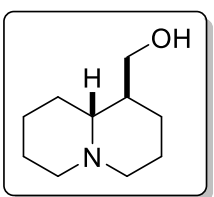

To a stirred solution of 1-(4-(1,3-dioxolan-2-yl)butyl)piperidine-2,6-dione 34 (25 $\mathrm{mg}, 0.103 \mathrm{mmol})$ in toluene $(1 \mathrm{~mL})$ is added $\mathrm{TfOH}(9.6 \mu \mathrm{L}, 0.108 \mathrm{mmol})$ and the mixture is heated at $90^{\circ} \mathrm{C}$ for 16 hours. The reaction is quenched with $\mathrm{NaHCO}_{3}$ $(10.5 \mathrm{mg}, 0.124 \mathrm{mmol})$ and $5 \mathrm{~mL}$ of water. The aqueous phase is extracted with DCM $(3 \times 2$ $\mathrm{mL}$ ), dried over anhydrous $\mathrm{MgSO}_{4}$ and concentrated under reduced pressure. The residue is dissolved in $\mathrm{Et}_{2} \mathrm{O}(5 \mathrm{~mL})$ under argon atmosphere, then $\mathrm{LiAlH}_{4}(19.7 \mathrm{mg}, 0.518 \mathrm{mmol})$ is added at $0^{\circ} \mathrm{C}$ and the reaction mixture is stirred for 8 hours. The reaction is sequentially quenched with $20 \mu \mathrm{L} \mathrm{H} \mathrm{H}_{2} \mathrm{O}, 20 \mu \mathrm{L} 10 \% \mathrm{NaOH}_{\text {(aq) }}, 60 \mu \mathrm{L} \mathrm{H} \mathrm{H}_{2} \mathrm{O}$ and dried over anhydrous $\mathrm{MgSO}_{4}$. The mixture is filtered through a pad of celite, while eluting with $\mathrm{Et}_{2} \mathrm{O}$, concentrated under reduced pressure and purified by flash column chromatography (7:3 $\mathrm{DCM}: \mathrm{MeOH})$ to afford the title compound as a light yellow oil: $8.5 \mathrm{mg}, 49 \%$. The spectroscopic data are identical to those previosly described. ${ }^{12}$

${ }^{1} \mathrm{H}$ NMR $\left(400 \mathrm{MHz}, \mathrm{CDCl}_{3}\right) \delta: 3.66(\mathrm{dd}, J=10.8 \mathrm{~Hz}, J=3.5 \mathrm{~Hz}, 1 \mathrm{H}), 3.58(\mathrm{dd}, J=10.8 \mathrm{~Hz}, J=$ $5.8 \mathrm{~Hz}, 1 \mathrm{H}), 2.90-2.76(\mathrm{~m}, 2 \mathrm{H}), 2.09-1.98(\mathrm{~m}, 2 \mathrm{H}), 1.92-1.57(\mathrm{~m}, 9 \mathrm{H}), 1.42(\mathrm{t}, J=17.3 \mathrm{~Hz}$, $1 \mathrm{H}), 1.30-1.17(\mathrm{~m}, 3 \mathrm{H})$. 
${ }^{13} \mathrm{C}$ NMR $\left(100 \mathrm{MHz}, \mathrm{CDCl}_{3}\right)$ ס: 64.6, 64.2, 56.8, 56.5, 43.8, 29.7, 28.1, 25.5, 24.9, 24.5.

IR (neat, ATR): 3321, 2939, 2831, 1662, 1446, 1111, 1022.

HRMS (ESI+): Calcd. for [ $\left.\mathrm{C}_{10} \mathrm{H}_{19} \mathrm{NO}+\mathrm{H}\right]^{+}:$170.1539, found: 170.1538 .

\section{2-(3-oxobutyl)isoindoline-1,3-dione (38)}

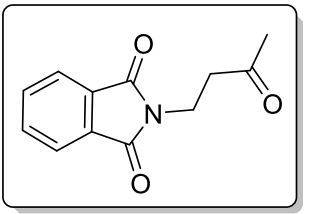

Similar to a procedure by Rasapalli and coworkers. ${ }^{1}$ To a solution of phthalimide $37(1.0 \mathrm{~g}, 6.79 \mathrm{mmol})$ in AcOEt $(15.0 \mathrm{~mL})$ is added EtONa (23 $\mathrm{mg}, 0.34 \mathrm{mmol}$ ) under argon atmosphere. After 15 minutes stirring at room temperature, MVK $12(624 \mu \mathrm{L}, 7.47 \mathrm{mmol})$ is added and the resulting mixture is refluxed at $77^{\circ} \mathrm{C}$ for 16 hours. Then, the reaction is cooled to room temperature and water is added. The aqueous phase is extracted with AcOEt $(3 \times 5 \mathrm{~mL})$, dried over anhydrous $\mathrm{MgSO}_{4}$ and concentrated under reduced pressure to afford the title compound as a beige solid: $1.47 \mathrm{~g}, 100 \%$. The spectroscopic data are identical to those previously described. ${ }^{13}$

'H NMR (400 MHz, CDCl $) \delta: 7.82(\mathrm{dd}, J=5.4 \mathrm{~Hz}, J=3.1 \mathrm{~Hz}, 2 \mathrm{H}), 7.70(\mathrm{dd}, J=5.4 \mathrm{~Hz}, J=$ $3.1 \mathrm{~Hz}, 2 \mathrm{H}$ ), 3.93 (t, $J=7.4 \mathrm{~Hz}, 2 \mathrm{H}$ ), 2.86 (t, $J=7.4 \mathrm{~Hz}, 2 \mathrm{H}$ ), 2.17 (s, 3H).

${ }^{13} \mathrm{C} \mathrm{NMR}\left(100 \mathrm{MHz}, \mathrm{CDCl}_{3}\right) \delta: 205.8,168.0,134.0,132.0,123.2,41.5,32.9,29.9$.

M.P.: $110-111^{\circ} \mathrm{C}$.

IR (neat, ATR): 1770, 1705, 1438, 1392, 1303, 1176.

HRMS (ESI+): Calcd. for $\left[\mathrm{C}_{12} \mathrm{H}_{11} \mathrm{NO}_{3}+\mathrm{Na}\right]^{+}: 240.0631$, found: 240.0629 .

\section{3,4-dihydropyrido[2,1-a]isoindole-2,6-dione (39)}

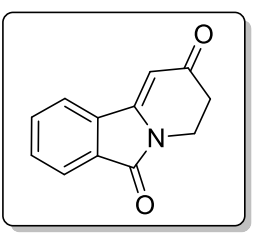

To a stirred solution of 2-(3-oxobutyl)isoindoline-1,3-dione $38(1.0 \mathrm{~g}, 4.62$ $\mathrm{mmol})$ in toluene $(20 \mathrm{~mL})$, is added $\mathrm{TfOH}(429 \mu \mathrm{L}, 4.85 \mathrm{mmol})$, and the mixture is heated at $90^{\circ} \mathrm{C}$ for $16 \mathrm{~h}$. The reaction is quenched with $\mathrm{NaHCO}_{3}$ (466 mg, $5.55 \mathrm{mmol}$ ) and $5 \mathrm{~mL}$ of water. The aqueous phase is extracted with DCM $(3 \times 5 \mathrm{~mL})$, dried over anhydrous $\mathrm{MgSO}_{4}$ and concentrated under reduced pressure. Purification by flash column chromatography (DCM) affords the title compound as an orange solid: $866 \mathrm{mg}, 94 \%$. The spectroscopic data are consistent with the literature. ${ }^{3}$

${ }^{1} \mathrm{H}$ NMR $\left(400 \mathrm{MHz}, \mathrm{CDCl}_{3}\right) \delta: 7.92-7.88(\mathrm{~m}, 1 \mathrm{H}), 7.77-7.72(\mathrm{~m}, 1 \mathrm{H}), 7.70-7.63(\mathrm{~m}, 2 \mathrm{H})$, $6.01(\mathrm{~s}, 1 \mathrm{H}), 4.13(\mathrm{t}, J=7.4 \mathrm{~Hz}, 2 \mathrm{H}), 2.77(\mathrm{t}, J=7.4 \mathrm{~Hz}, 2 \mathrm{H})$. 
${ }^{13} \mathrm{C} \mathrm{NMR}\left(100 \mathrm{MHz}, \mathrm{CDCl}_{3}\right) \delta: 193.6,166.0,151.1,134.2,132.9,132.3,129.8,124.1,122.0$, 101.8, 37.2, 35.5.

M.P.: $185^{\circ} \mathrm{C}$.

IR (neat, ATR): 3062, 2978, 1705, 1616, 1354, 1122.

HRMS (ESI+): Calcd. for [ $\left.\mathrm{C}_{12} \mathrm{H}_{9} \mathrm{NO}_{2}+\mathrm{H}\right]^{+}:$200.0706, found: 200.0710 .

\section{1,3,4,10b-tetrahydropyrido[2,1-a]isoindol-6(2H)-one (41)}

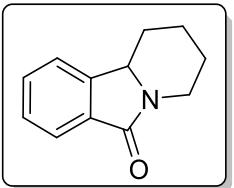

A mixture containing $80 \mathrm{mg}(0.40 \mathrm{mmol})$ of 3,4-dihydropyrido[2,1-a]isoindole2,6-dione $39,43 \mathrm{mg}(0.04 \mathrm{mmol})$ of $10 \% \mathrm{Pd} / \mathrm{C}$ and $5 \mathrm{~mL}$ of AcOEt is subjected to a $\mathrm{H}_{2}$ atmosphere ( $\left.1 \mathrm{~atm}\right)$ for 12 hours. Then, the reaction mixture is filtered through a pad of celite and the solvent is removed under reduced pressure to afford a white solid. Then, a procedure similar to those reported by Rotier and coworkers is employed. ${ }^{7}$ The crude reaction mixture $\left(74 \mathrm{mg}\right.$ ) and $\mathrm{H}_{2} \mathrm{NNH}_{2} \cdot \mathrm{H}_{2} \mathrm{O} 55 \%$ (132 $\mu \mathrm{L}, 1.48 \mathrm{mmol}$ ) were added to a solution containing sodium ( $25 \mathrm{mg}, 1.1 \mathrm{mmol}$ ) in $2.96 \mathrm{~mL}$ of ethylene glycol. Then, the mixture is refluxed at $140^{\circ} \mathrm{C}$ for $4 \mathrm{~h}$ and left to cool to room temperature. Then, DCM ( $\left.5 \mathrm{~mL}\right)$ is added and the organic phase is washed with $1 \mathrm{M}$ aqueous solution of $\mathrm{NaOH}(5 \mathrm{~mL})$, dried over anhydrous $\mathrm{MgSO}_{4}$ and purified by flash column chromatography (95:5 DCM:MeOH) to afford the title compound as a colorless oil: $56 \mathrm{mg}, 74 \%$. The spectroscopic data are consistent with those in the literature. ${ }^{14}$

${ }^{1} \mathrm{H}$ NMR $\left(400 \mathrm{MHz}, \mathrm{CDCl}_{3}\right) \delta: 7.84(\mathrm{~d}, J=7.4 \mathrm{~Hz}, 1 \mathrm{H}), 7.51$ (t, $\left.J=7.4 \mathrm{~Hz}, 1 \mathrm{H}\right), 7.42$ (dd, $J=$ $17.4 \mathrm{~Hz}, J=7.4 \mathrm{~Hz}, 2 \mathrm{H}$ ), 4.47 (dd, $J=13.2 \mathrm{~Hz}, J=4.9 \mathrm{~Hz}, 1 \mathrm{H}$ ), 4.25 (dd, $J=11.9 \mathrm{~Hz}, J=3.6$ $\mathrm{Hz}, 1 \mathrm{H}$ ), $2.96(\mathrm{td}, J=13.2 \mathrm{~Hz}, J=3.6 \mathrm{~Hz}, 1 \mathrm{H}), 2.34(\mathrm{dd}, J=12.9 \mathrm{~Hz}, J=3.2 \mathrm{~Hz}, 1 \mathrm{H}$ ), $2.03-$ $1.93(\mathrm{~m}, 1 \mathrm{H}), 1.81(\mathrm{~d}, J=13.2 \mathrm{~Hz}, 1 \mathrm{H}), 1.65$ (qt, $J=13.2 \mathrm{~Hz}, J=3.4 \mathrm{~Hz}, 1 \mathrm{H}), 1.38$ (tdd, $J=$ $17.5 \mathrm{~Hz}, J=8.6 \mathrm{~Hz}, J=4.3 \mathrm{~Hz}, 1 \mathrm{H}), 1.11(\mathrm{dd}, J=12.8 \mathrm{~Hz}, J=3.4 \mathrm{~Hz}, 1 \mathrm{H})$.

${ }^{13} \mathrm{C}$ NMR $\left(100 \mathrm{MHz}, \mathrm{CDCl}_{3}\right) \delta: 166.1,145.7,132.4,131.0,128.0,123.7,121.6,58.9,39.6$, 31.7, 25.2, 23.6.

IR (neat, ATR): 2927, 1666, 1616, 1269, 1284.

HRMS (ESI+): Calcd. for [ $\left.\mathrm{C}_{12} \mathrm{H}_{13} \mathrm{NO}+\mathrm{Na}\right]^{+}:$210.0889, found: 210.0892 . 


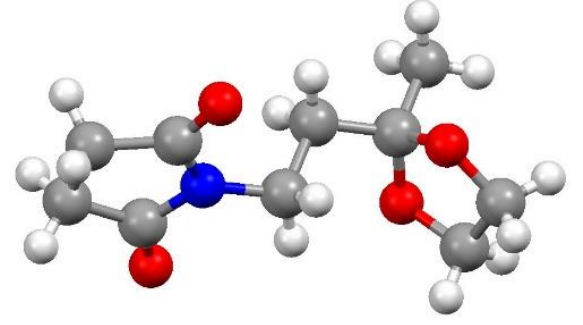

Bond precision: $\mathrm{C}-\mathrm{C}=0.0021 \mathrm{~A}$ Wavelength: 0.71073

Cell: $\quad a=9.3566(12) \quad b=5.8094(7) \quad c=19.075(3)$ alpha $=90 \quad$ beta $=98.014(2) \quad$ gamma $=90$

Temperature: $150 \mathrm{~K}$

\begin{tabular}{|l|l|l|}
\hline & Calculated & Reported \\
\hline Volume & $1026.7(2)$ & $1026.7(2)$ \\
\hline Space group & $\mathrm{P} 21 / \mathrm{n}$ & $\mathrm{P} 21 / \mathrm{n}$ \\
\hline Hall group & $-\mathrm{P} 2 \mathrm{yn}$ & $-\mathrm{P} 2 \mathrm{yn}$ \\
\hline Moiety formula & $\mathrm{C}_{10} \mathrm{H}_{15} \mathrm{NO}_{4}$ & $\mathrm{C}_{10} \mathrm{H}_{15} \mathrm{NO}_{4}$ \\
\hline Sum formula & $\mathrm{C}_{10} \mathrm{H}_{15} \mathrm{NO}_{4}$ & $\mathrm{C}_{10} \mathrm{H}_{15} \mathrm{NO}_{4}$ \\
\hline Mr & 213.23 & 213.23 \\
\hline Dx,g cm & \\
\hline Z & 1.380 & 1.379 \\
\hline Mu (mm & \\
\hline F000 & 4 & 4 \\
\hline F000' & 0.107 & 0.106 \\
\hline h, k, Imax & 456.0 & 456.0 \\
\hline Nref & 456.26 & \\
\hline Tmin,Tmax & $12,7,25$ & $12,7,25$ \\
\hline Tmin' & 2556 & 2551 \\
\hline & $0.965,0.976$ & $0.653,0.746$ \\
\hline
\end{tabular}

Correction method $=$ \# Reported T Limits: Tmin $=0.653$ Tmax=0.746 AbsCorr $=$ MULTISCAN

Data completeness $=0.988 \quad$ Theta $(\max )=28.321$

$\mathbf{R}$ (reflections) $=0.0477(2265) \quad \mathbf{w R}$ (reflections) $=0.1356(2551)$

$S=1.054$

Npar $=137$ 
3,4-dihydropyrido[2,1-a]isoindole-2,6-dione (39)

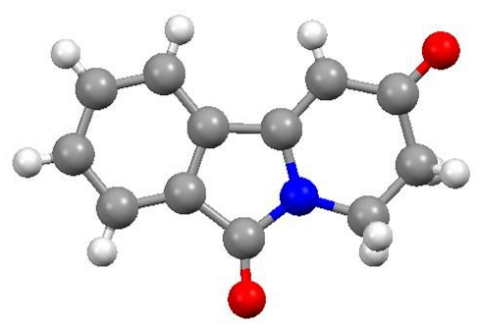

Bond precision: $\mathrm{C}-\mathrm{C}=0.0034 \mathrm{~A}$ Wavelength: 1.54178

Cell: $\quad a=10.5173(4) \quad b=6.1177(3) \quad c=14.7799(6)$

alpha $=90$

beta $=98.308(2) \quad$ gamma $=90$

Temperature: $296 \mathrm{~K}$

\begin{tabular}{|c|c|c|}
\hline & Calculated & Reported \\
\hline Volume & $940.98(7)$ & $940.98(7)$ \\
\hline Space group & $P 21 / n$ & $P 21 / n$ \\
\hline Hall group & $-P 2 y n$ & $-P 2 y n$ \\
\hline Moiety formula & $\mathrm{C}_{12} \mathrm{H}_{9} \mathrm{NO}_{2}$ & $\mathrm{C}_{12} \mathrm{H}_{9} \mathrm{NO}_{2}$ \\
\hline Sum formula & $\mathrm{C}_{12} \mathrm{H}_{9} \mathrm{NO}_{2}$ & $\mathrm{C}_{12} \mathrm{H}_{9} \mathrm{NO}_{2}$ \\
\hline Mr & 199.20 & 199.20 \\
\hline $\mathrm{Dx}, \mathrm{g} \mathrm{cm}^{-3}$ & 1.406 & 1.406 \\
\hline $\mathbf{Z}$ & 4 & 4 \\
\hline $\operatorname{Mu}\left(\mathrm{mm}^{-1}\right)$ & 0.793 & 0.793 \\
\hline F000 & 416.0 & 416.0 \\
\hline F000' & 417.32 & \\
\hline h, k, Imax & $12,7,17$ & $12,7,17$ \\
\hline Nref & 1753 & 1710 \\
\hline Tmin,Tmax & $0.818,0.850$ & $0.629,0.753$ \\
\hline Tmin' & 0.679 & \\
\hline
\end{tabular}

Correction method $=$ \# Reported T Limits: Tmin $=0.629$ Tmax $=0.753 \quad$ AbsCorr $=$ MULTISCAN

Data completeness $=0.975 \quad$ Theta $(\max )=68.836$

$\mathbf{R}$ (reflections) $=0.0668(1607) \quad \mathbf{R} 2$ (reflections) $=0.1732(1710)$

$S=1.059 \quad$ Npar $=137$ 


\section{NMR spectra}

1-(3-oxobutyl)pyrrolidine-2,5-dione (13)<smiles>CC(=O)CCN1C(=O)CCC1=O</smiles>
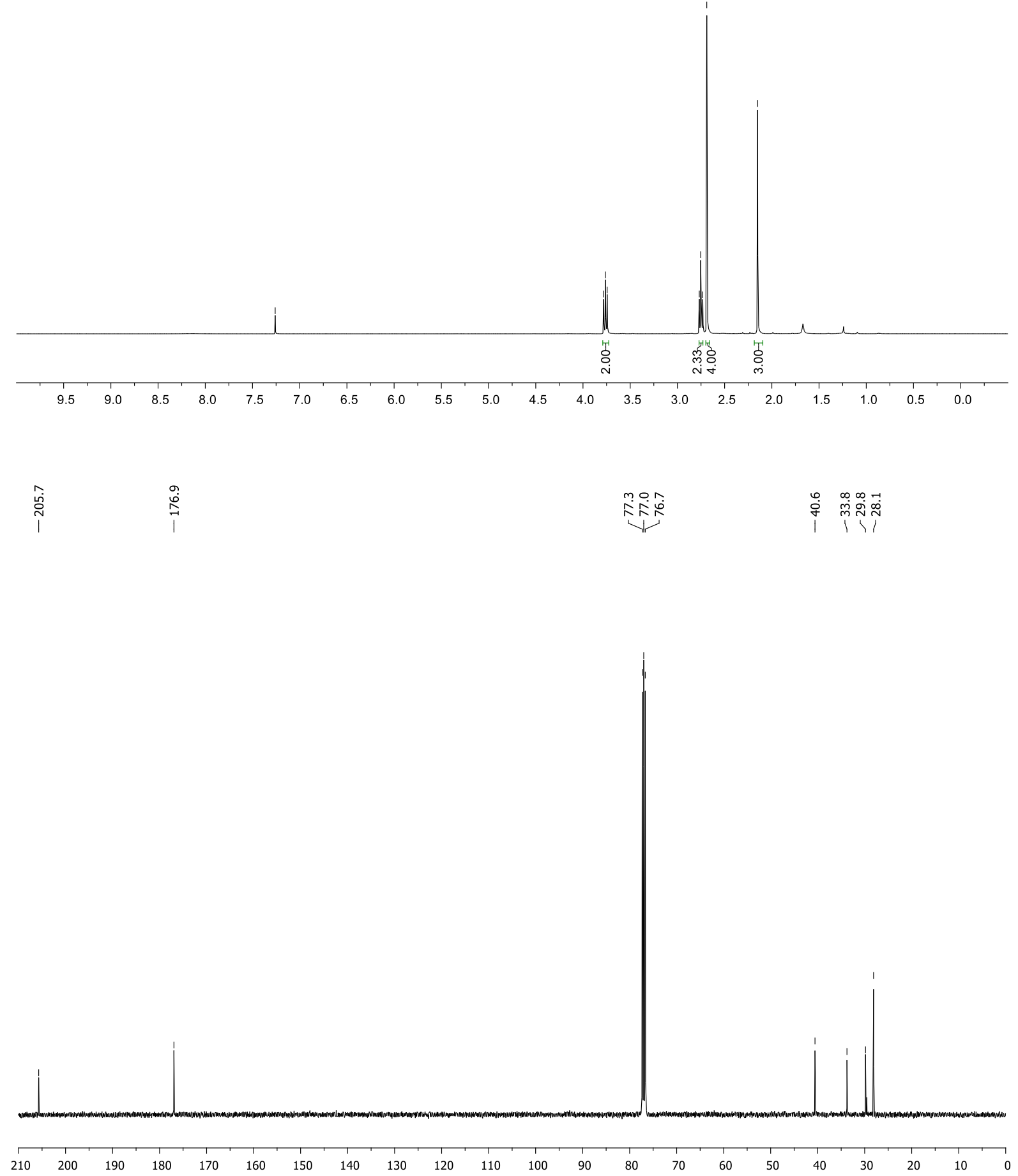
1,2,5,6-tetrahydroindolizine-3,7-dione (14)<smiles>O=C1C=C2CCC(=O)N2CC1</smiles>

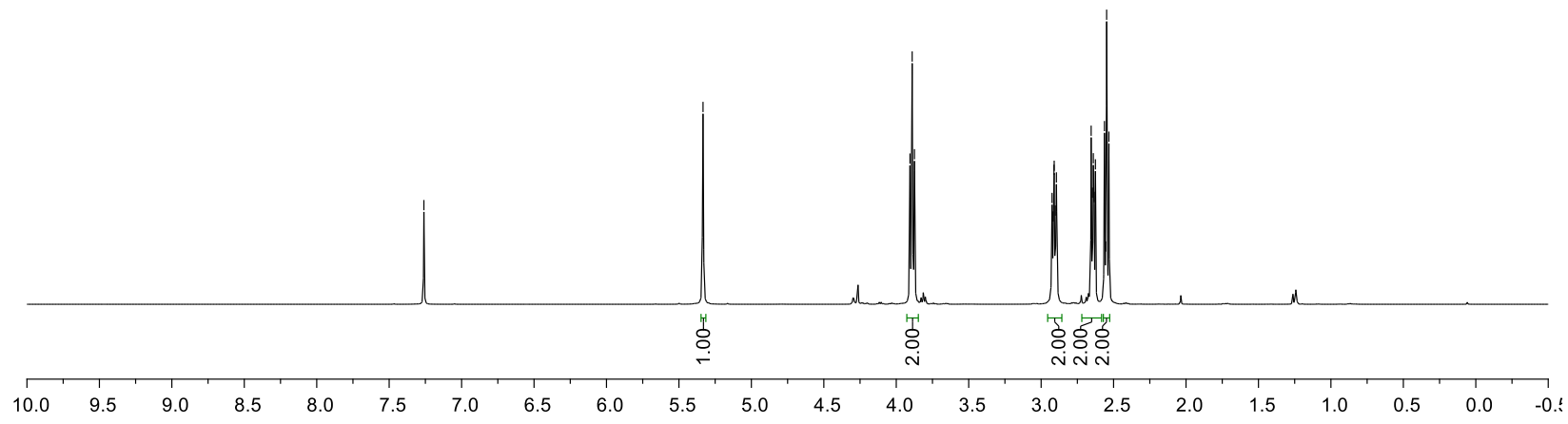

\begin{tabular}{|c|c|c|c|}
\hline$\frac{i}{\stackrel{i}{i}}$ & $\frac{\hat{n}}{\dot{0}}$ & 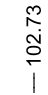 & 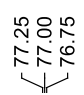 \\
\hline
\end{tabular}

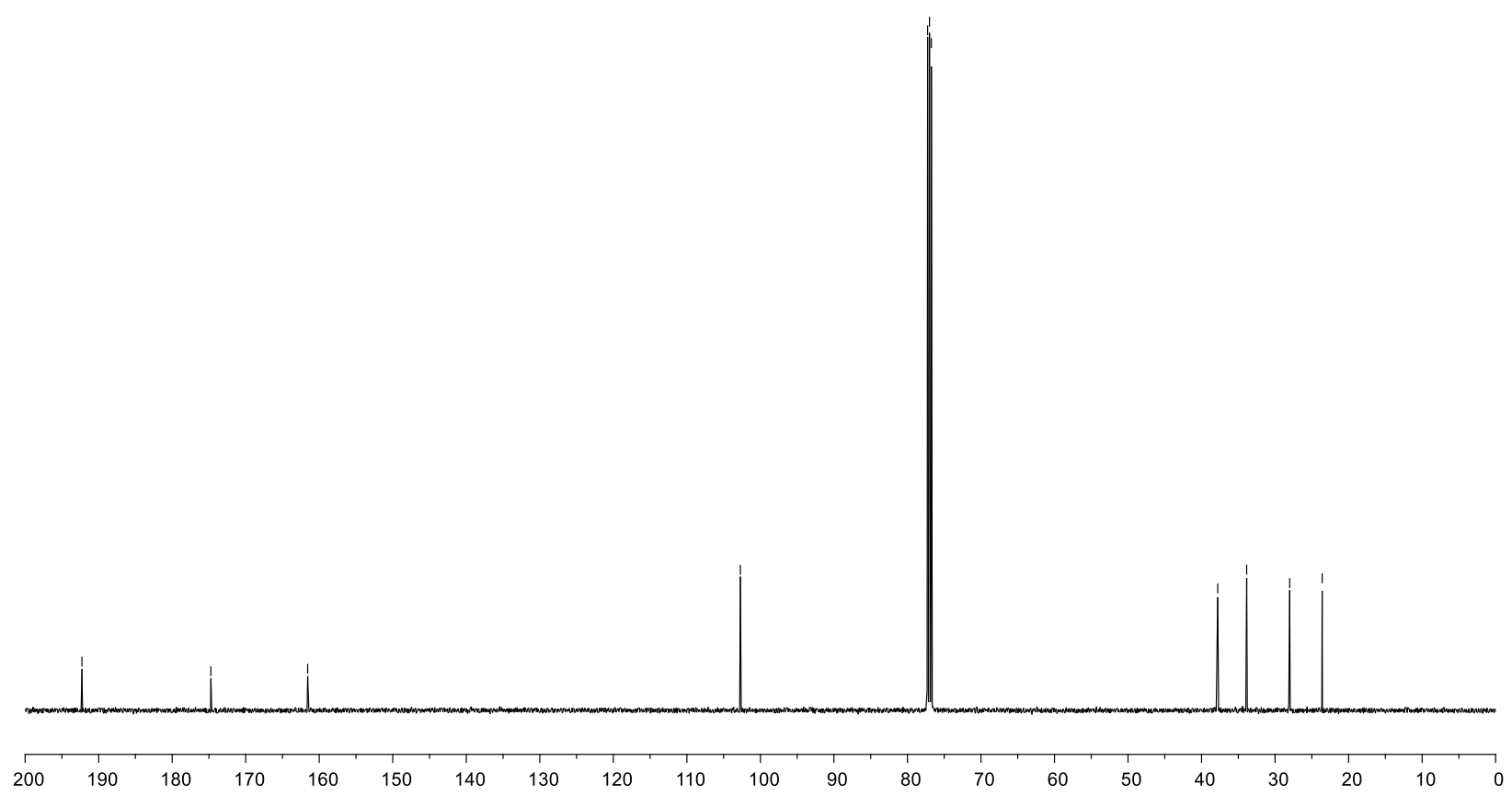


Hexahydroindolizin-3(2H)-one (15)<smiles>O=C1CCC2CCCCN12</smiles>

15

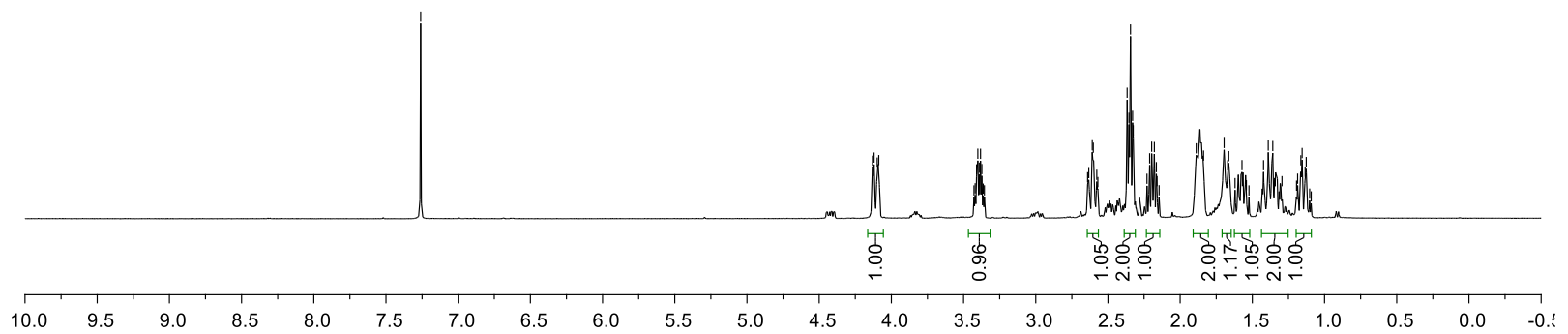

舀

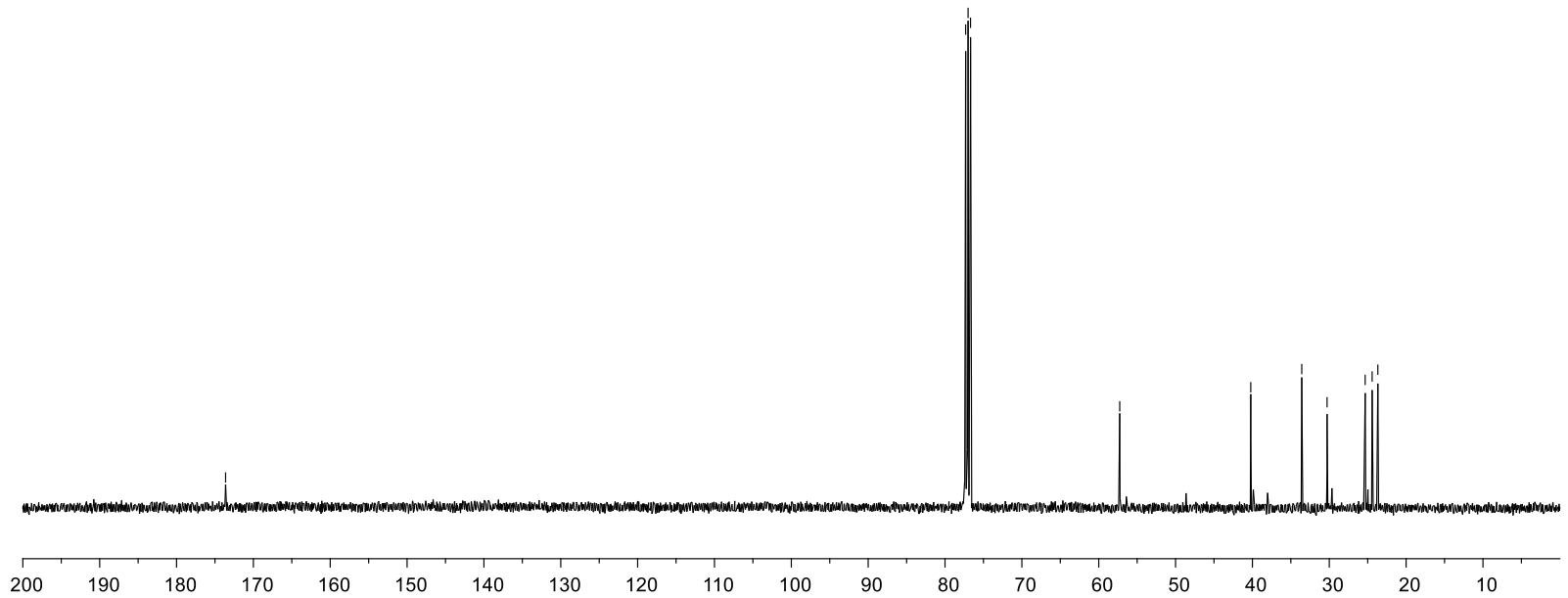


(士)-Coniceine (16)

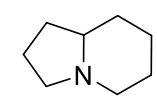

16
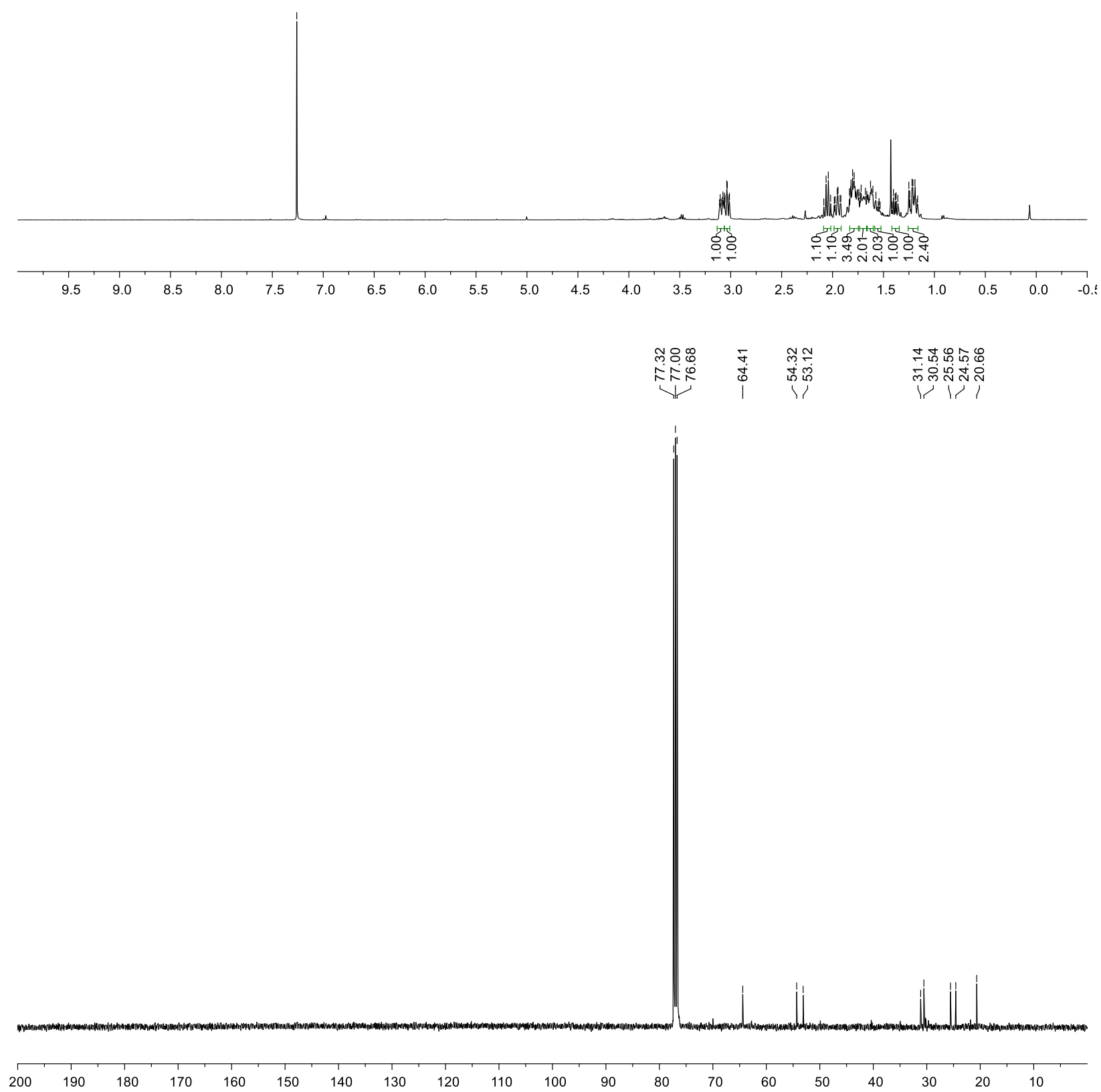
1-(3-oxobutyl)piperidine-2,6-dione (18)

$\stackrel{\substack{i \\ i}}{i}$

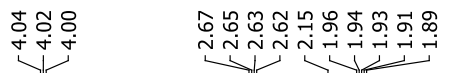<smiles>CC(=O)CCN1C(=O)CCCC1=O</smiles>

18

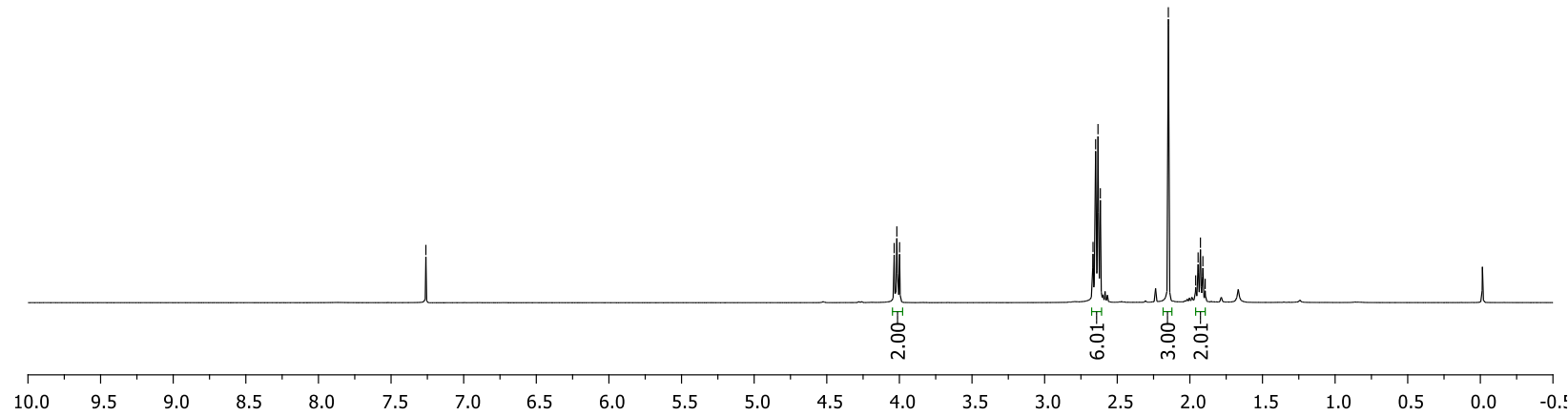

\begin{tabular}{|c|c|c|}
\hline $\begin{array}{l}\stackrel{8}{\circ} \\
\stackrel{8}{\circ} \\
\text { i }\end{array}$ & $\underset{\substack{\stackrel{N}{N}\\
}}{\stackrel{1}{N}}$ & 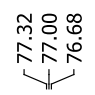 \\
\hline
\end{tabular}

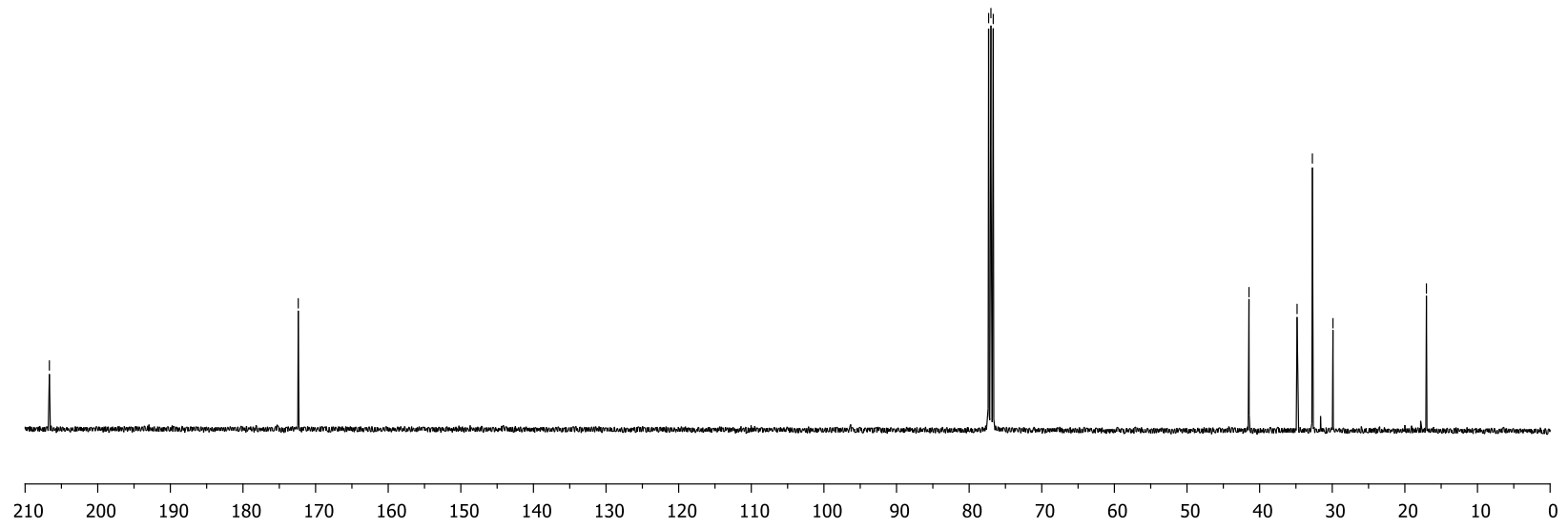


3,4,8,9-tetrahydro-2H-quinolizine-2,6(7H)-dione (19)
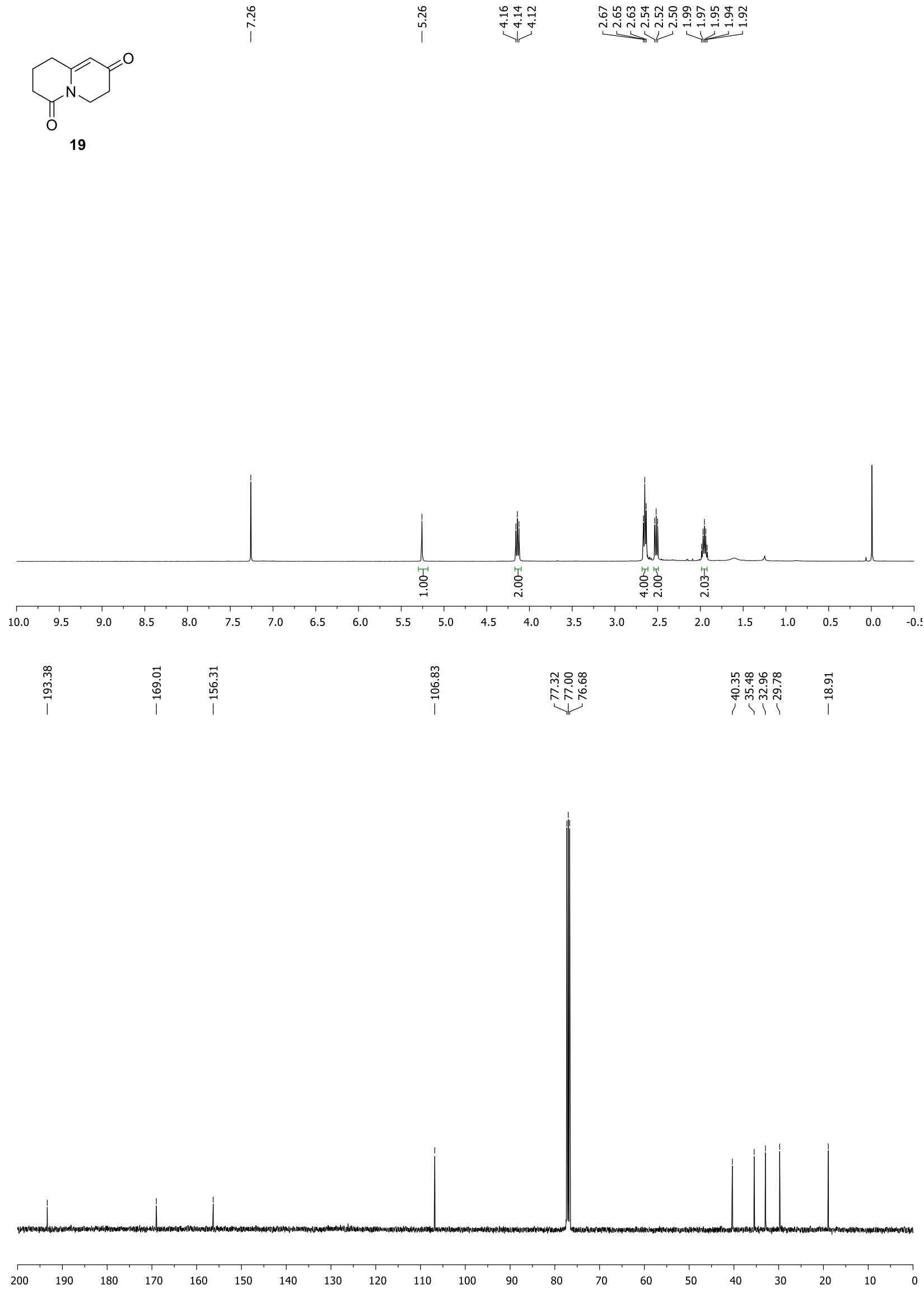
Octahydro-4H-quinolizin-4-one (20)

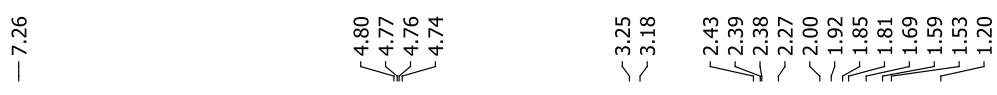<smiles>O=C1CCCC2CCCCN12</smiles>

20

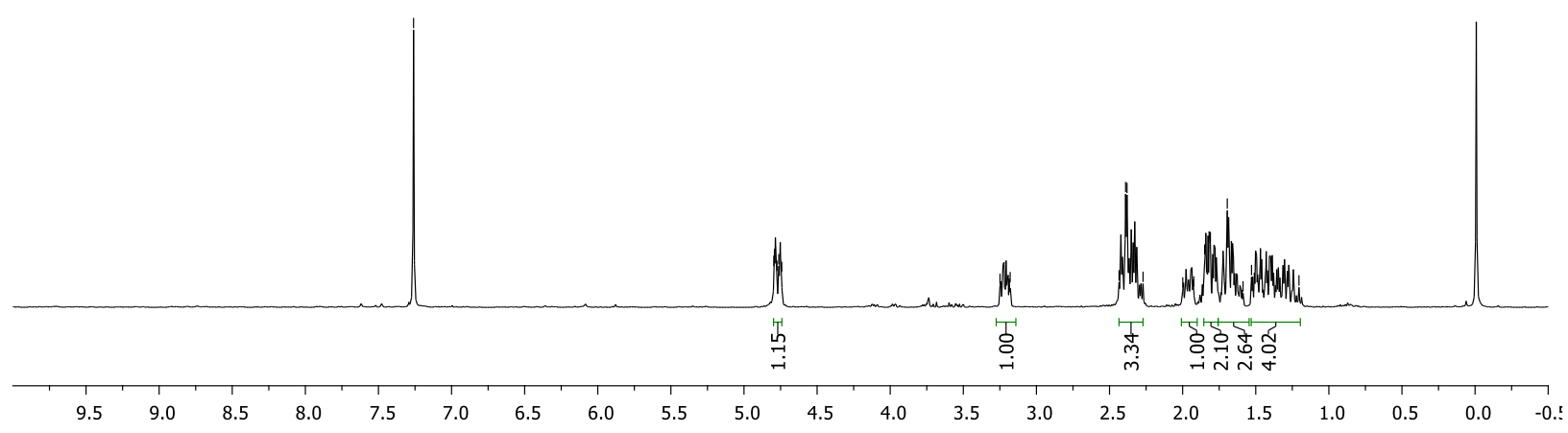

ஸి

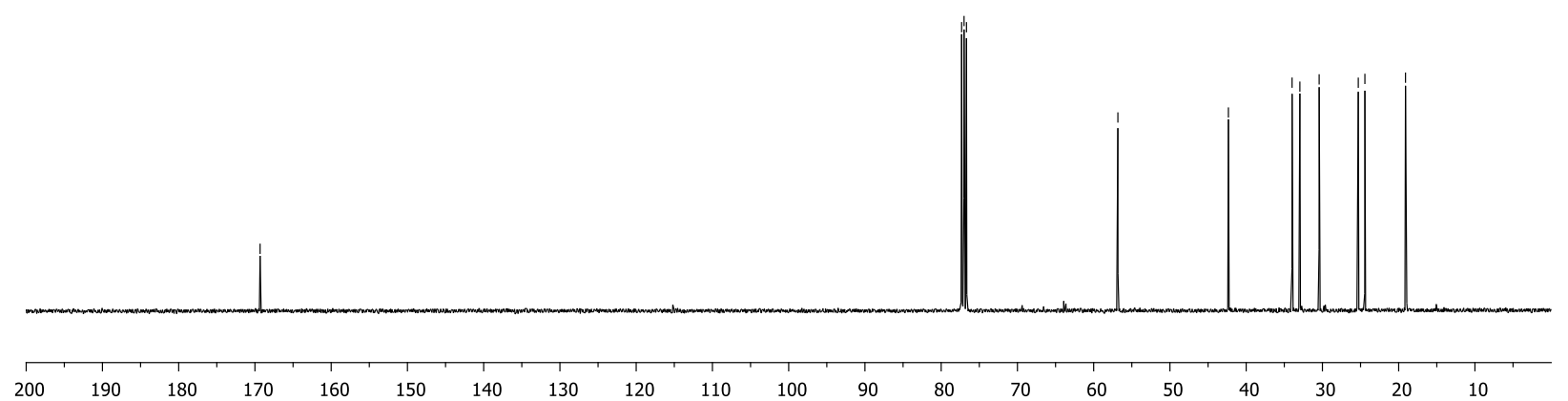


Hexahydro-2H-quinolizine-2,6(1H)-dione (21)
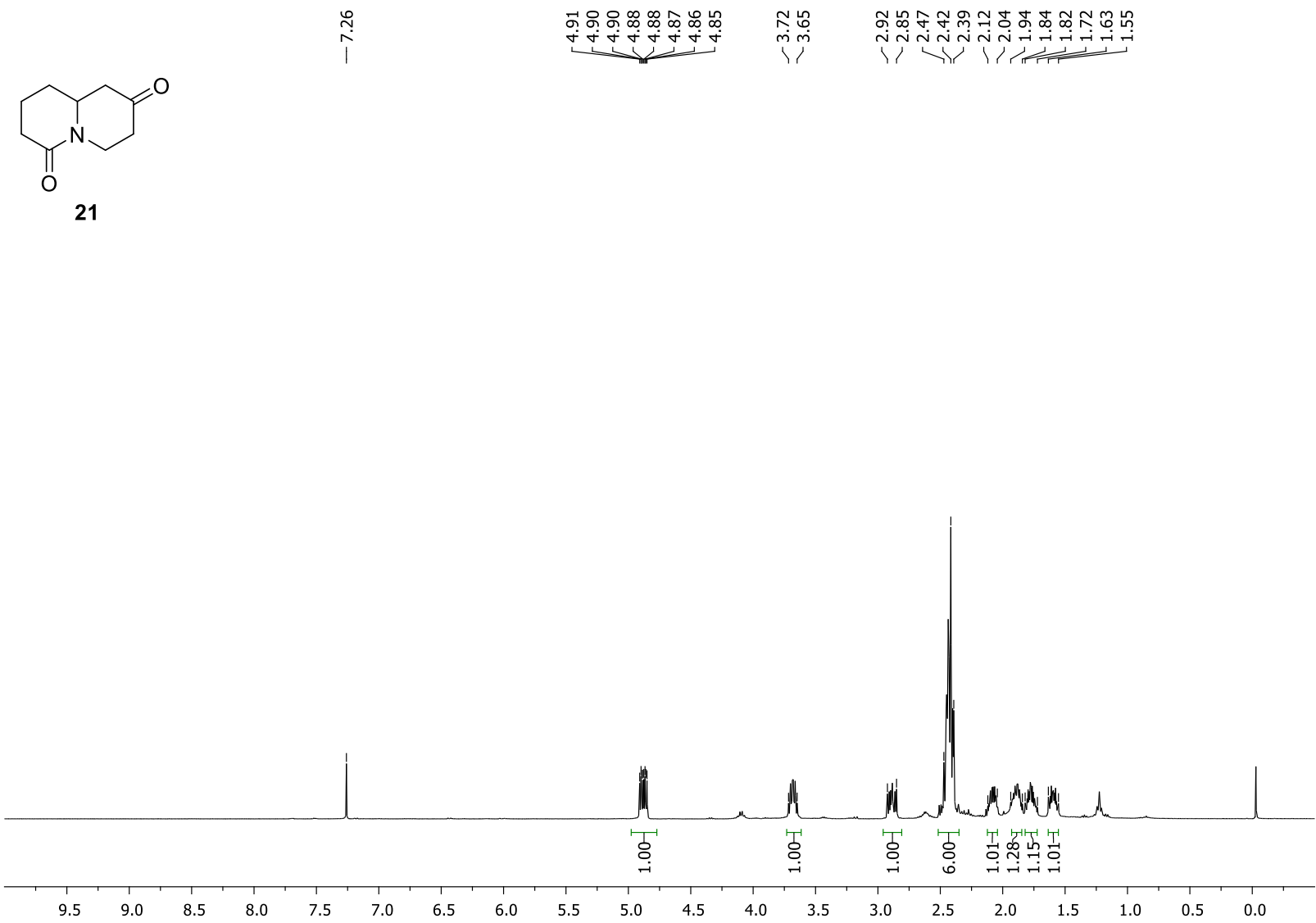

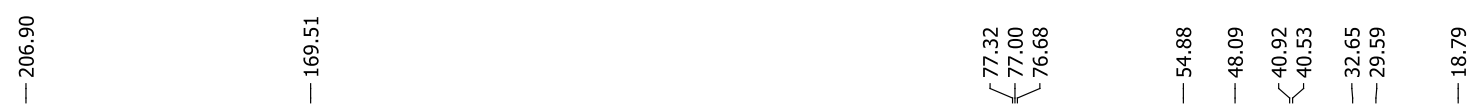

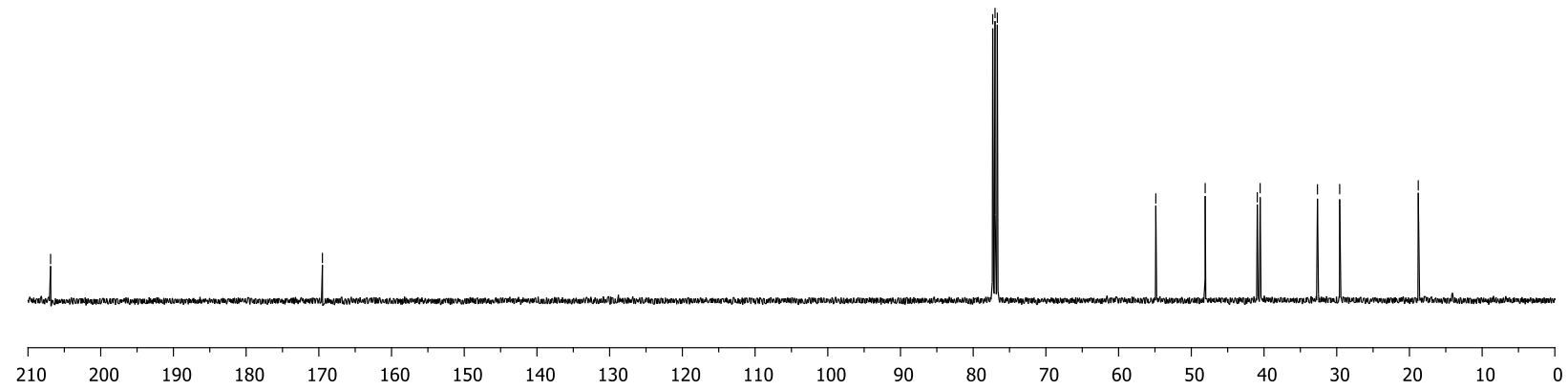


( \pm )-Quinolizidine (22)<smiles>C1CCN2CCCCC2C1</smiles>

22
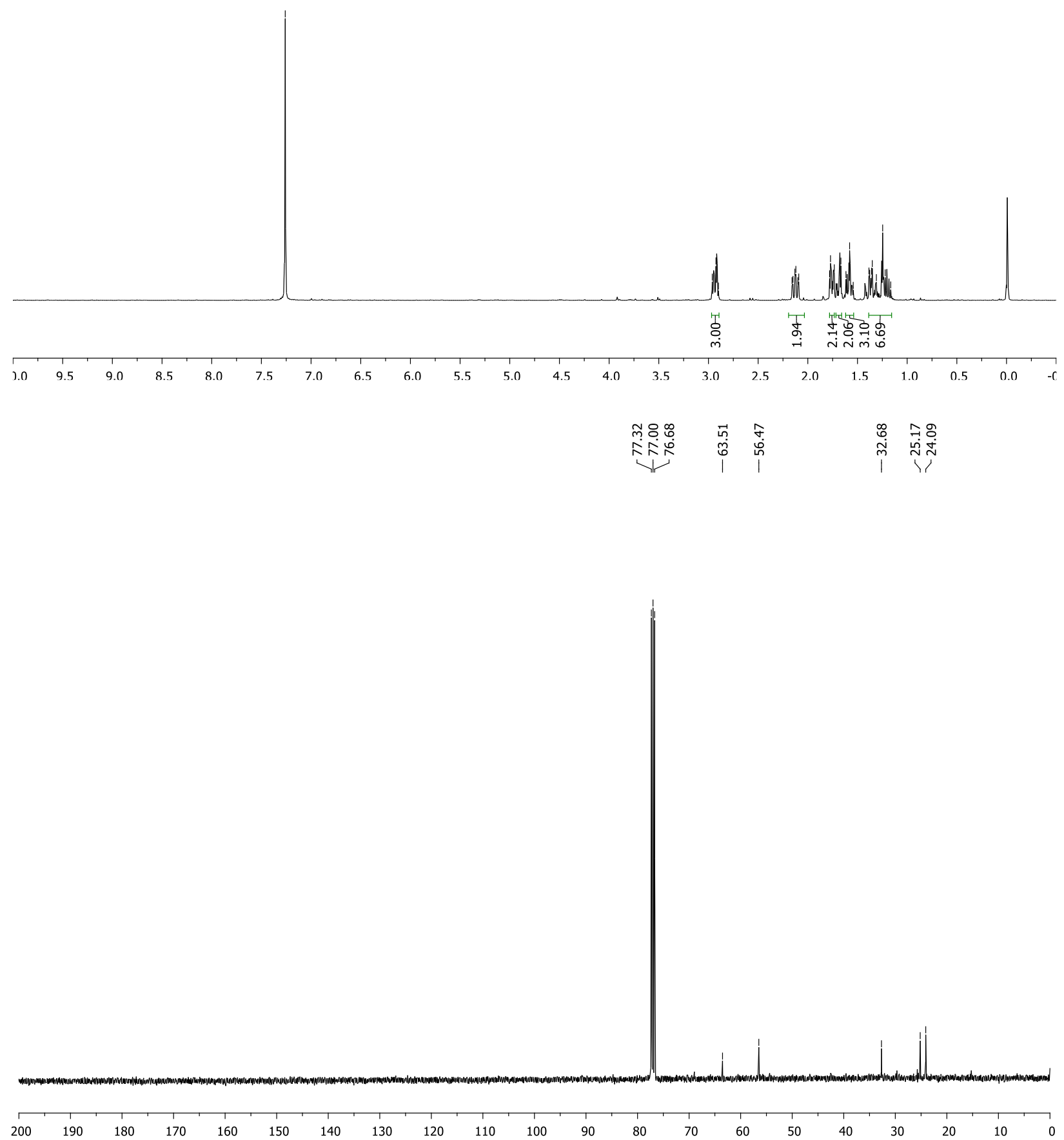
1-(2-(2-methyl-1,3-dioxolan-2-yl)ethyl)pyrrolidine-2,5-dione (23)<smiles>CC1(C)OCCO1</smiles>

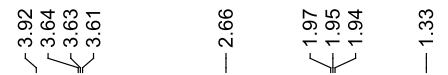

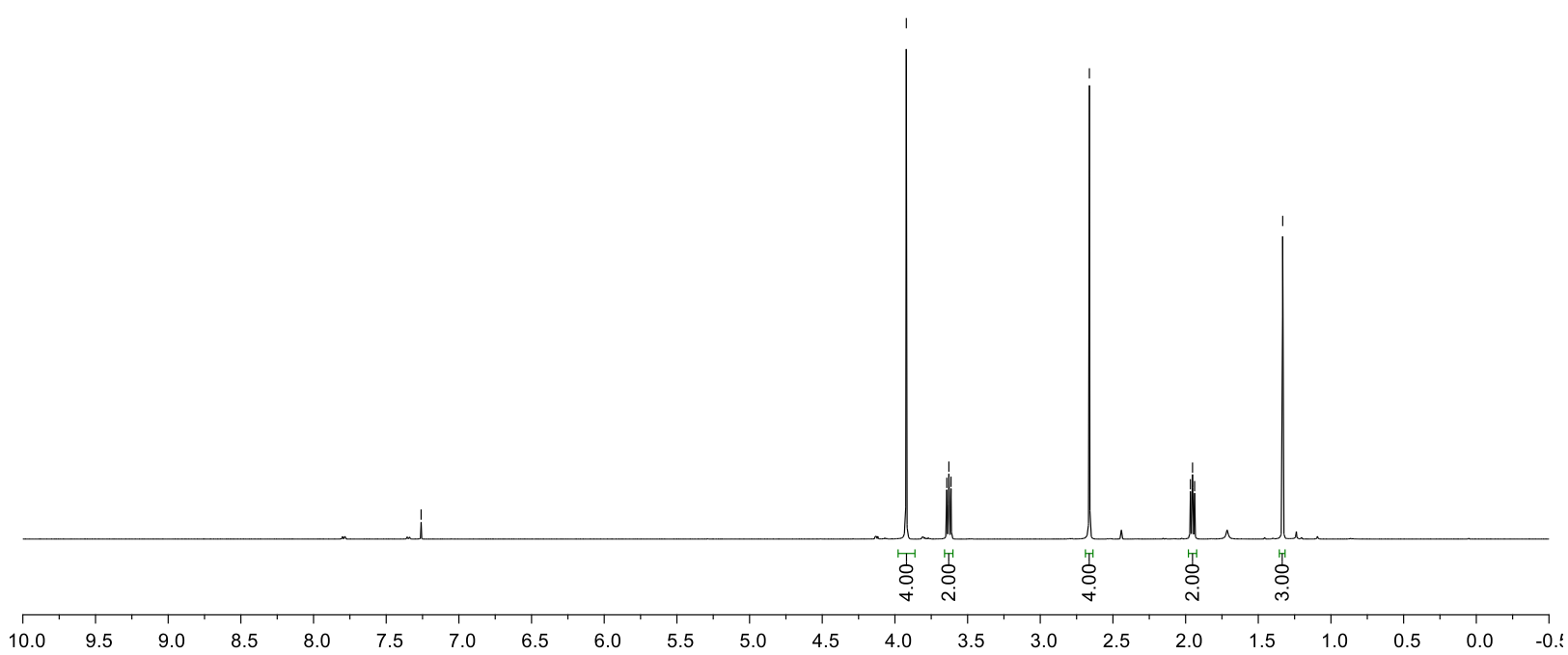

\begin{tabular}{|c|c|c|c|c|}
\hline & $\begin{array}{l}\infty \\
\infty \\
\infty \\
\stackrel{0}{1} \\
1\end{array}$ & 等是 & & 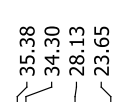 \\
\hline
\end{tabular}

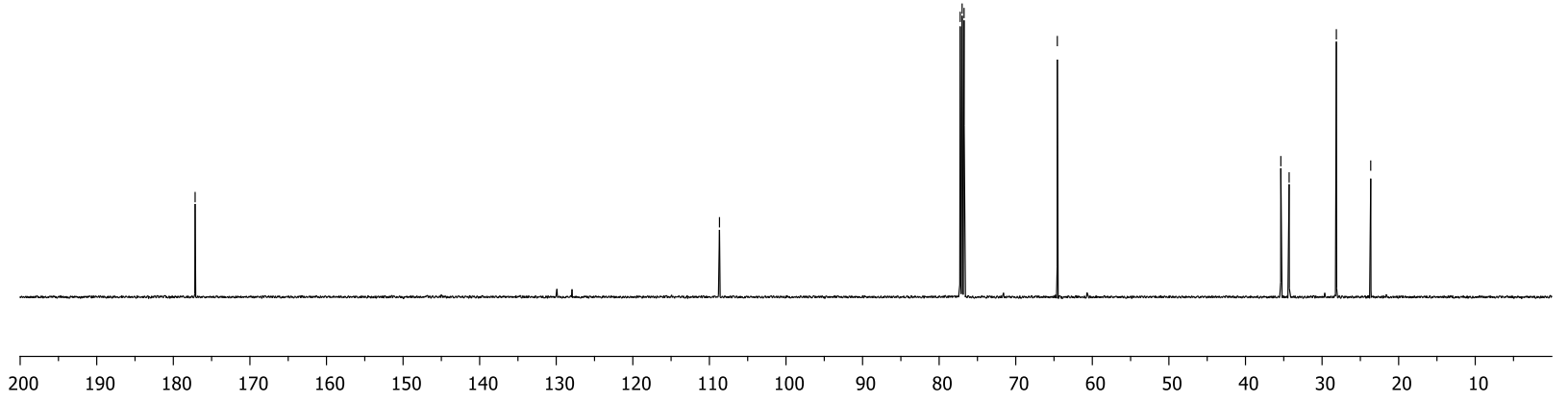


1-(2-(2-methyl-1,3-dioxolan-2-yl)ethyl)piperidine-2,6-dione (24)
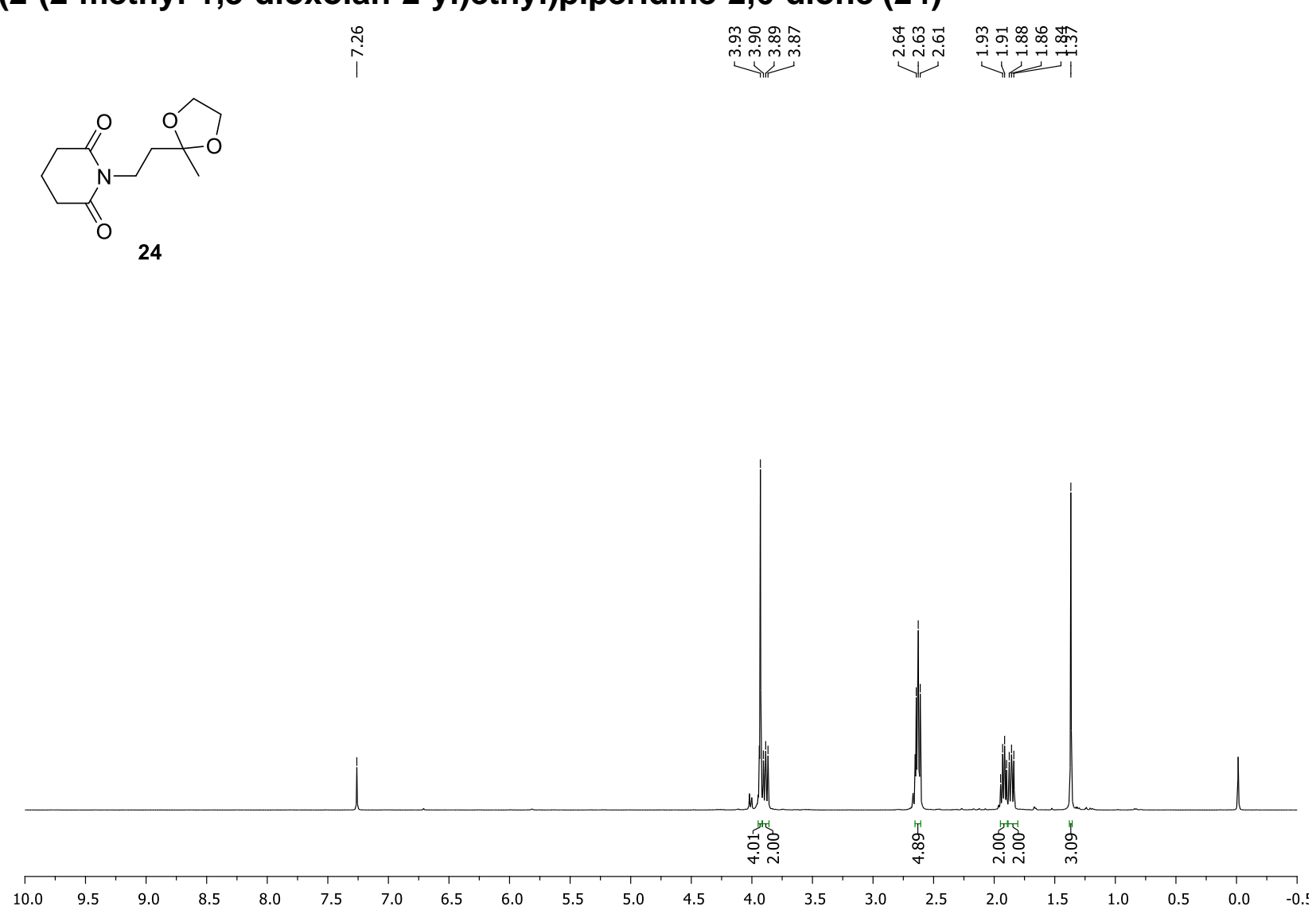

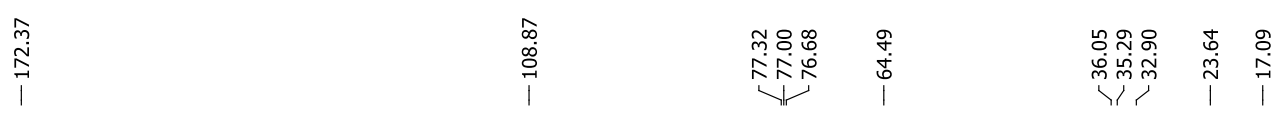

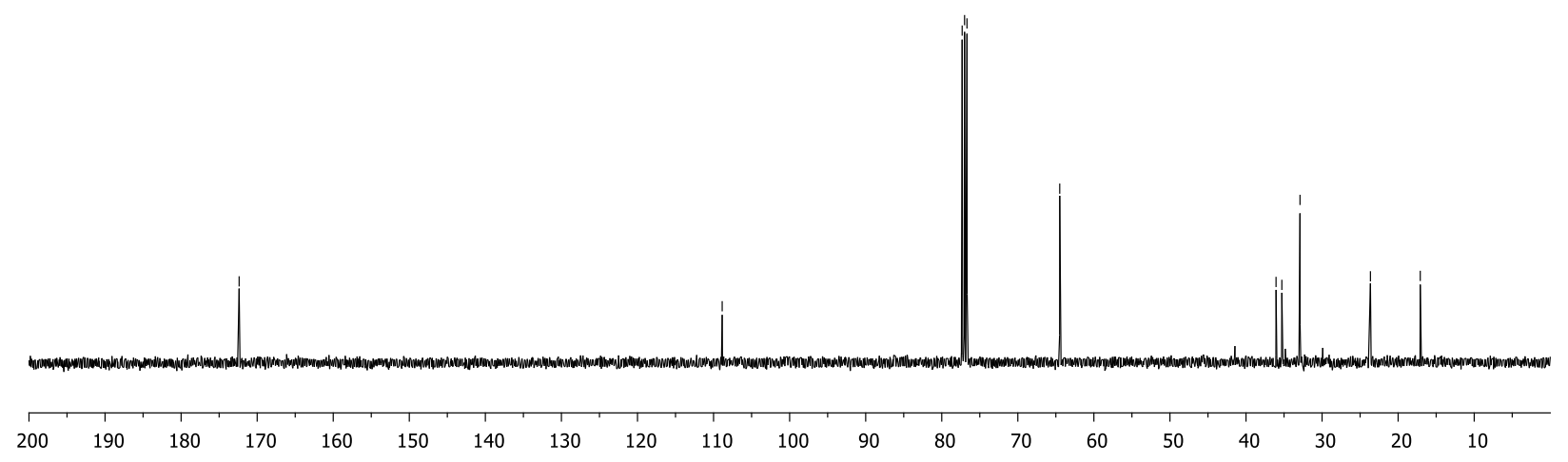


1-(hex-5-en-1-yl)pyrrolidine-2,5-dione (26)

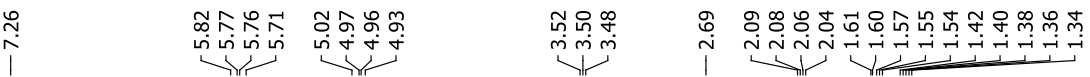<smiles>C=CCCCCN1C(=O)CCC1=O</smiles>

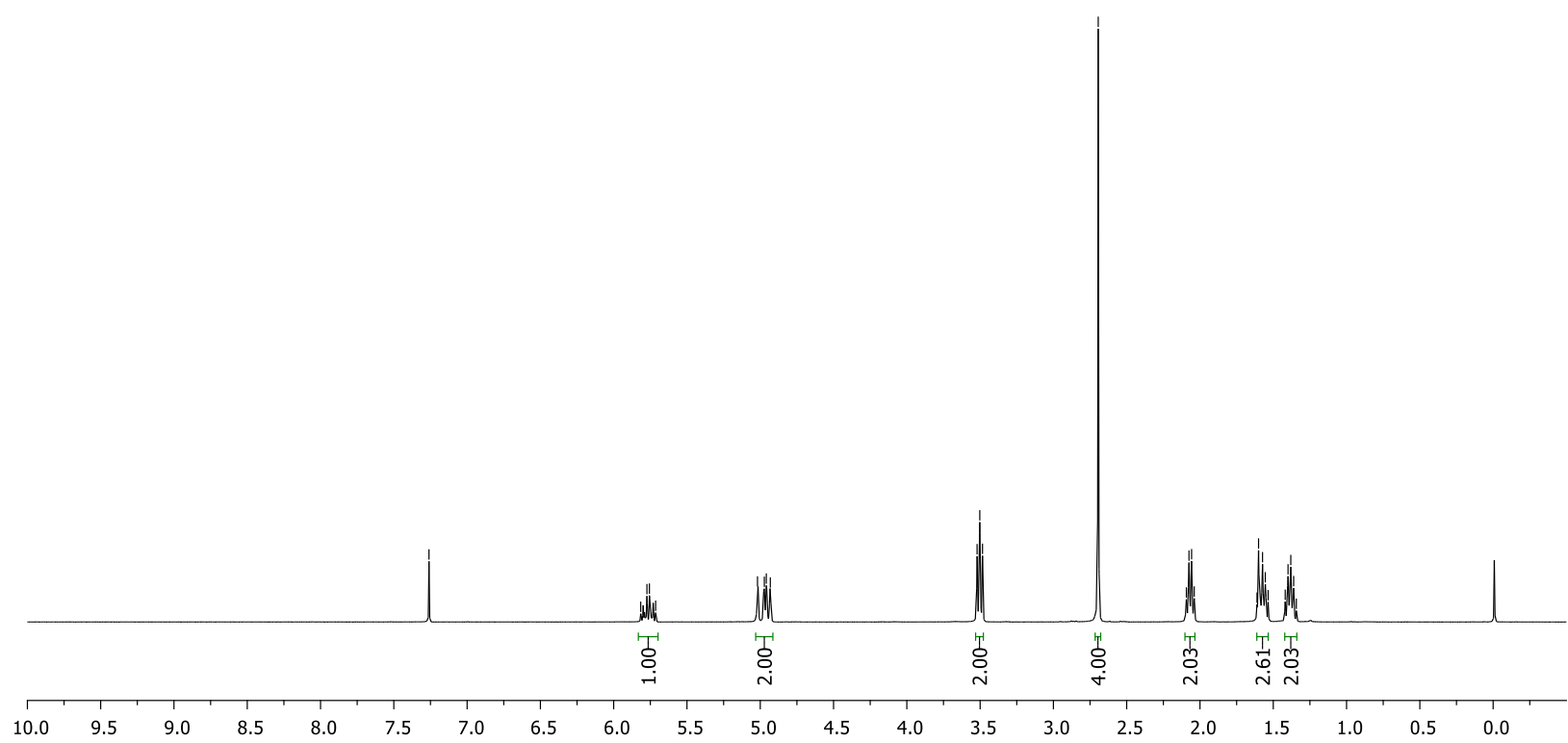

点

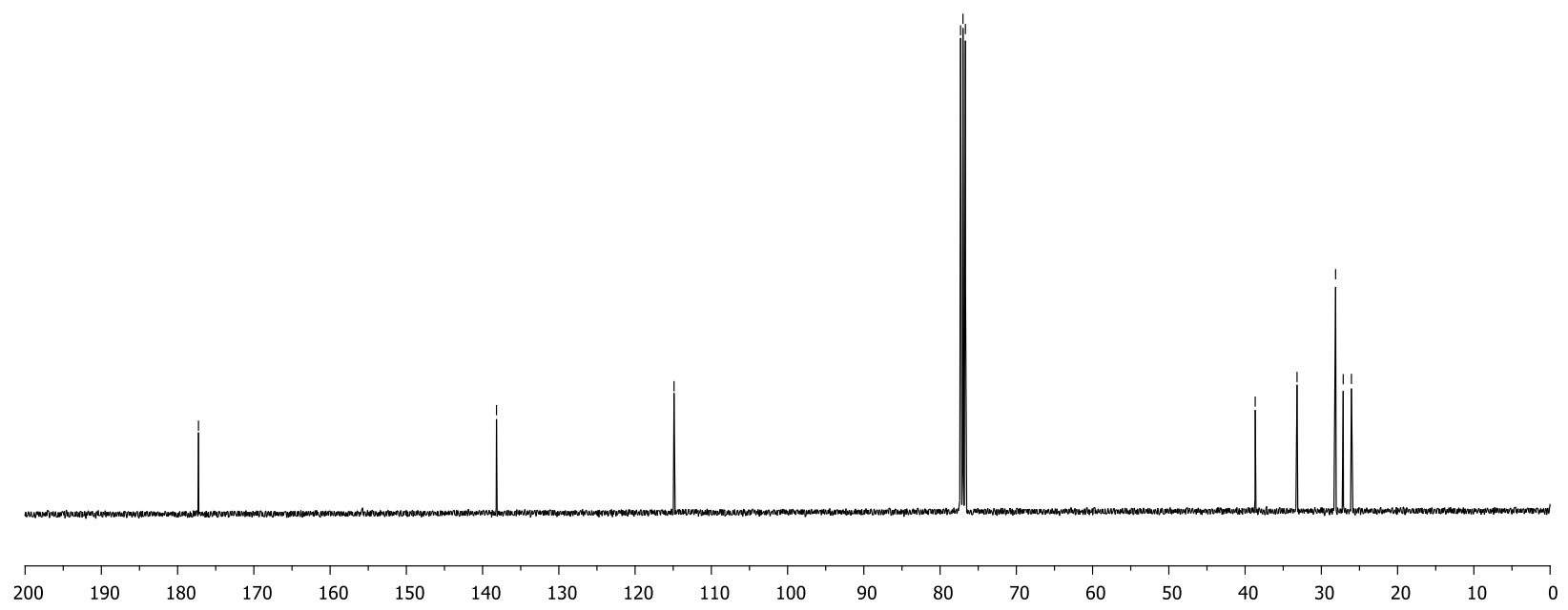


5-(2,5-dioxopyrrolidin-1-yl)pentanal (27)

동

बูंสू

$\stackrel{\stackrel{\imath}{i}}{i}$

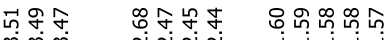

mंm Ninin<smiles>O=CCCCCN1C(=O)CCC1=O</smiles>

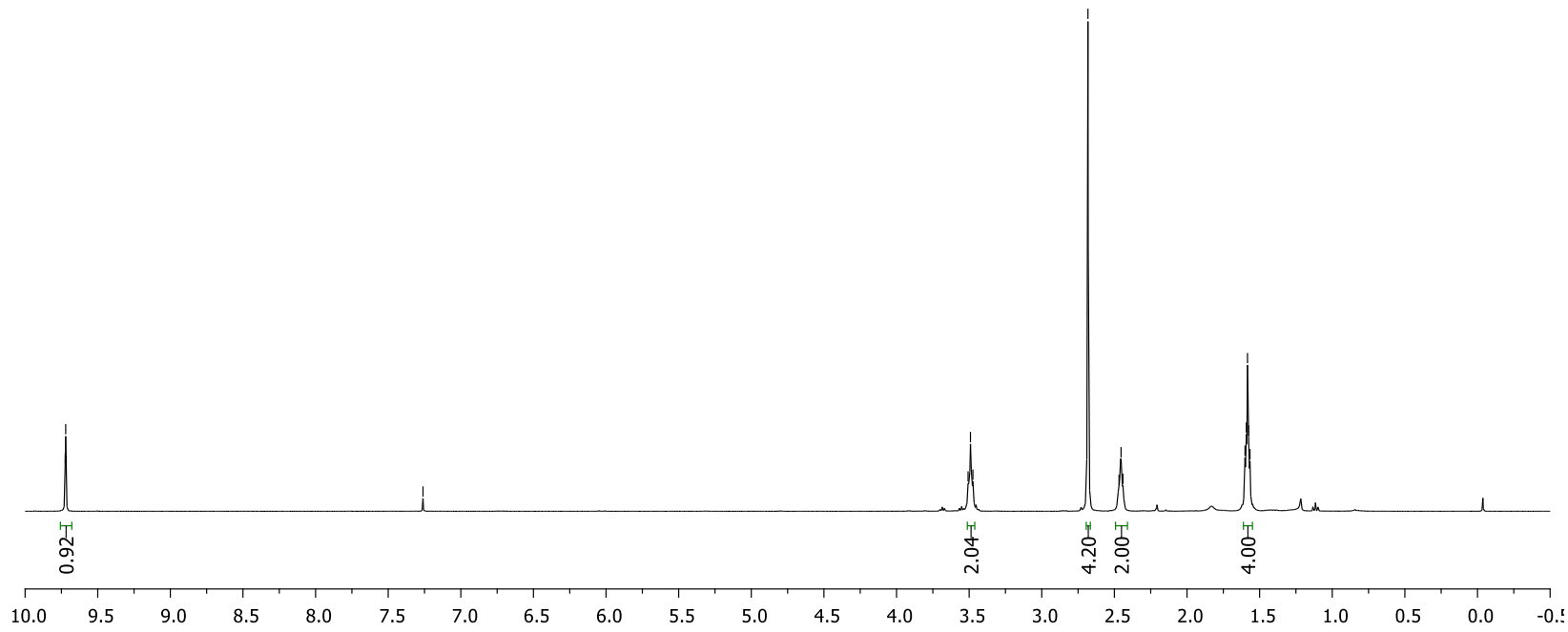

\begin{tabular}{|c|c|c|}
\hline 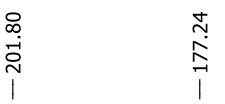 & 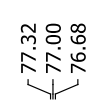 & 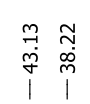 \\
\hline
\end{tabular}

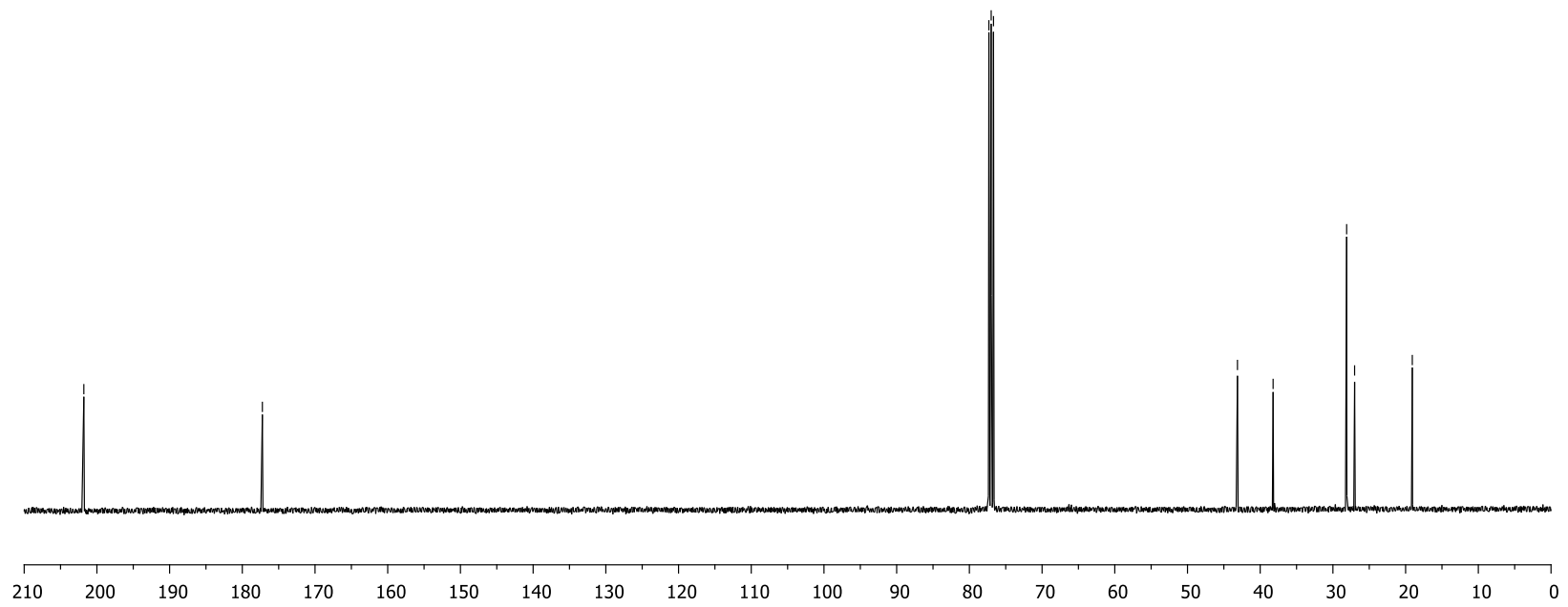


1-(4-(1,3-dioxolan-2-yl)butyl)pyrrolidine-2,5-dione (28)

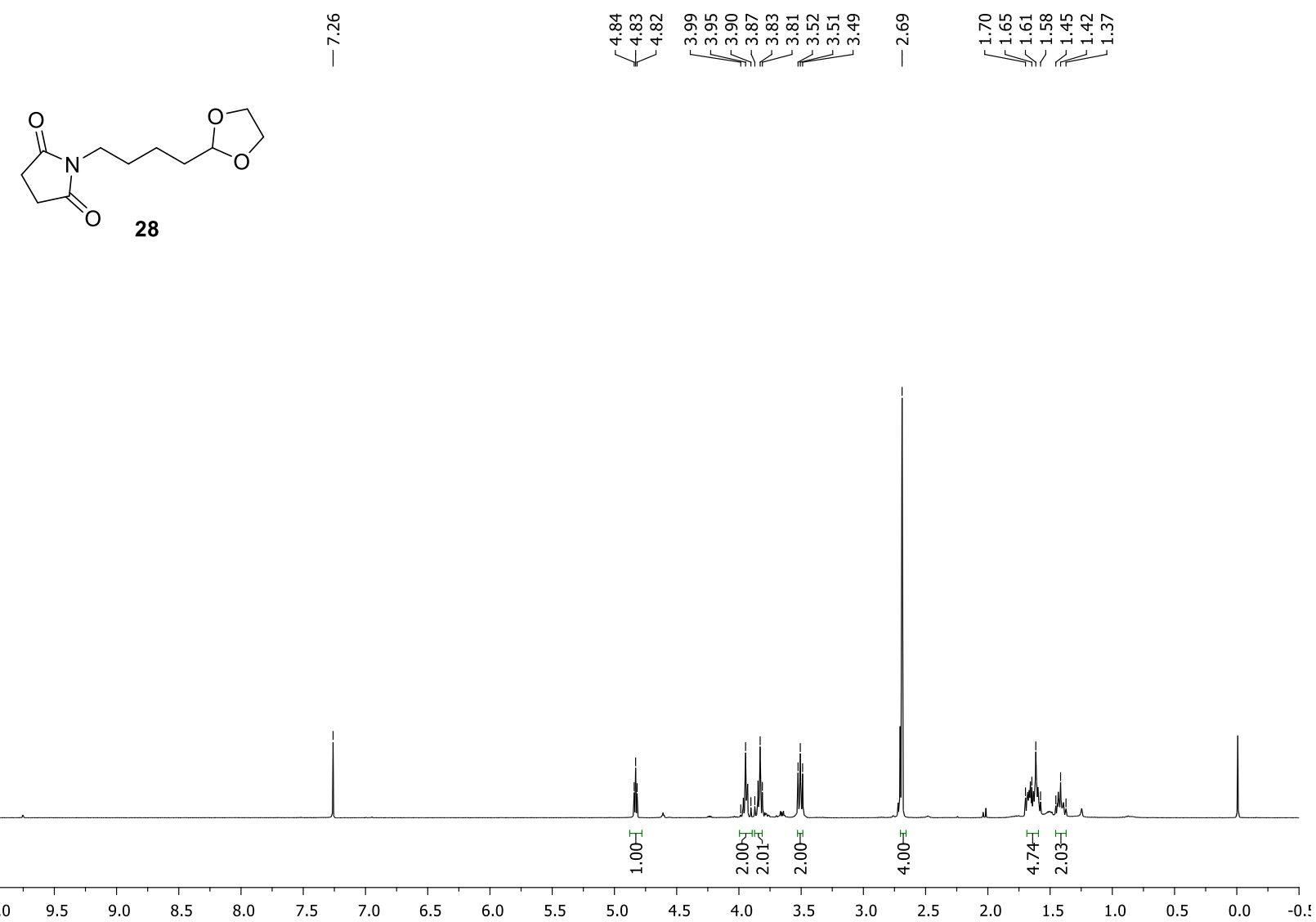

\begin{tabular}{|c|c|c|}
\hline$\approx$ & $\begin{array}{l}\stackrel{ }{~} \\
\text { ப் } \\
\stackrel{-}{\mid}\end{array}$ & m̃o \\
\hline
\end{tabular}

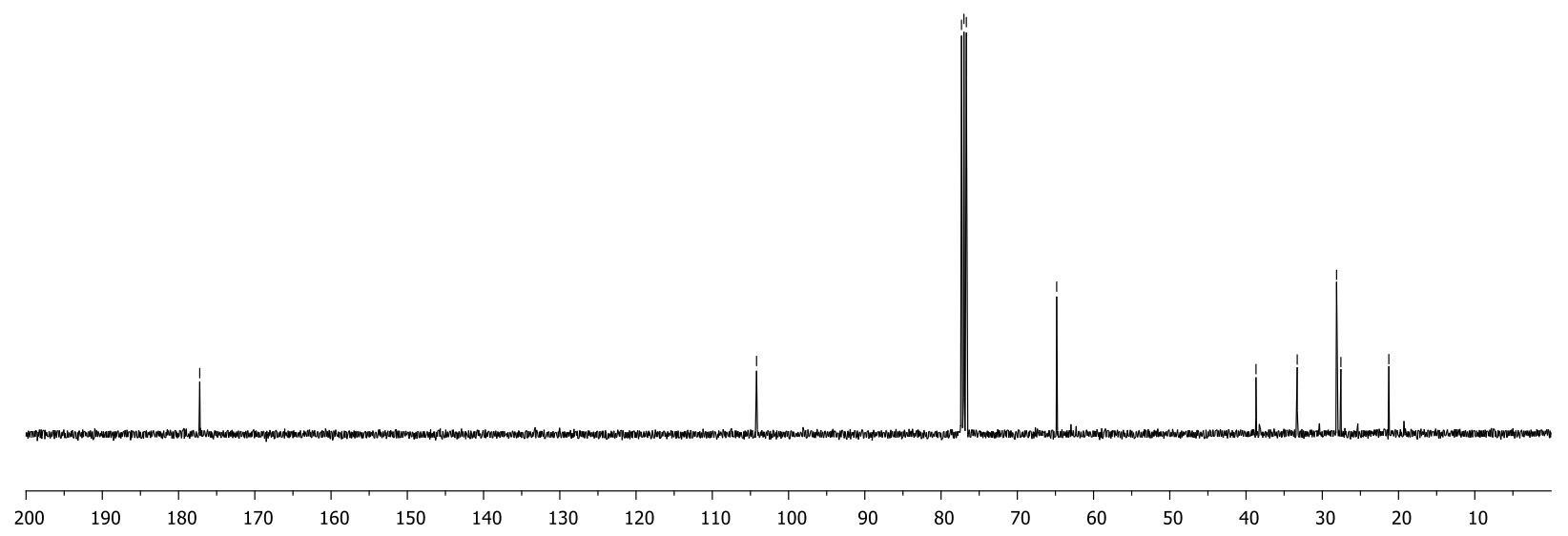


(士)-Tashiromine (30)<smiles>OCC1CCCN2CCCC12</smiles>

30

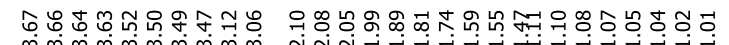

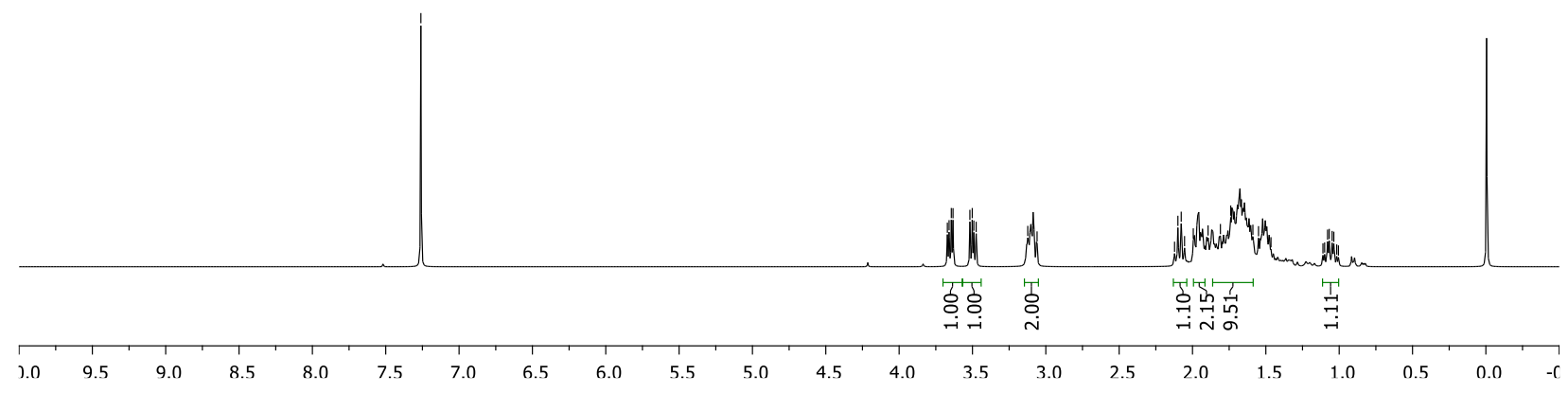

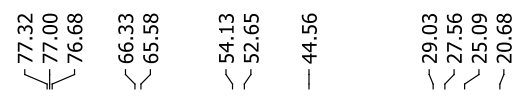

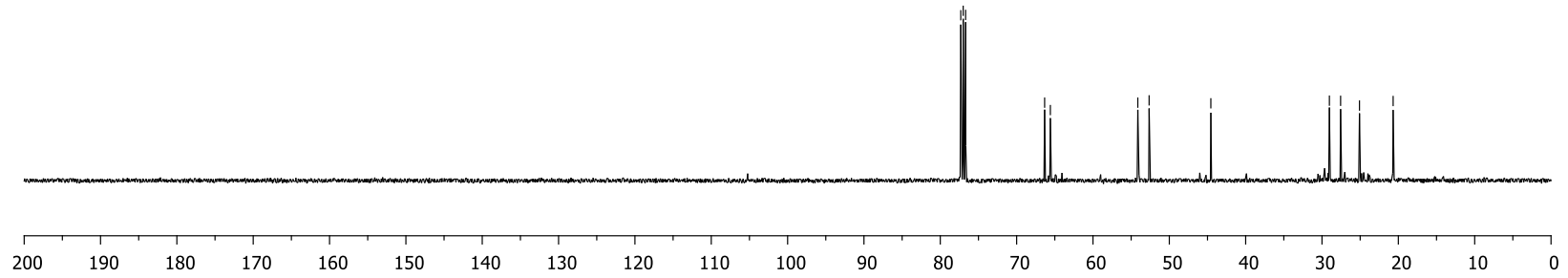


1-(hex-5-en-1-yl)piperidine-2,6-dione (32)

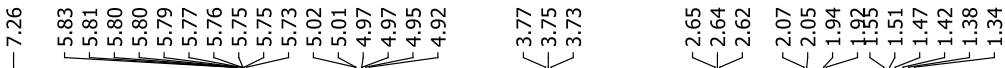<smiles>C=CCCCCN1C(=O)CCCC1=O</smiles>

32

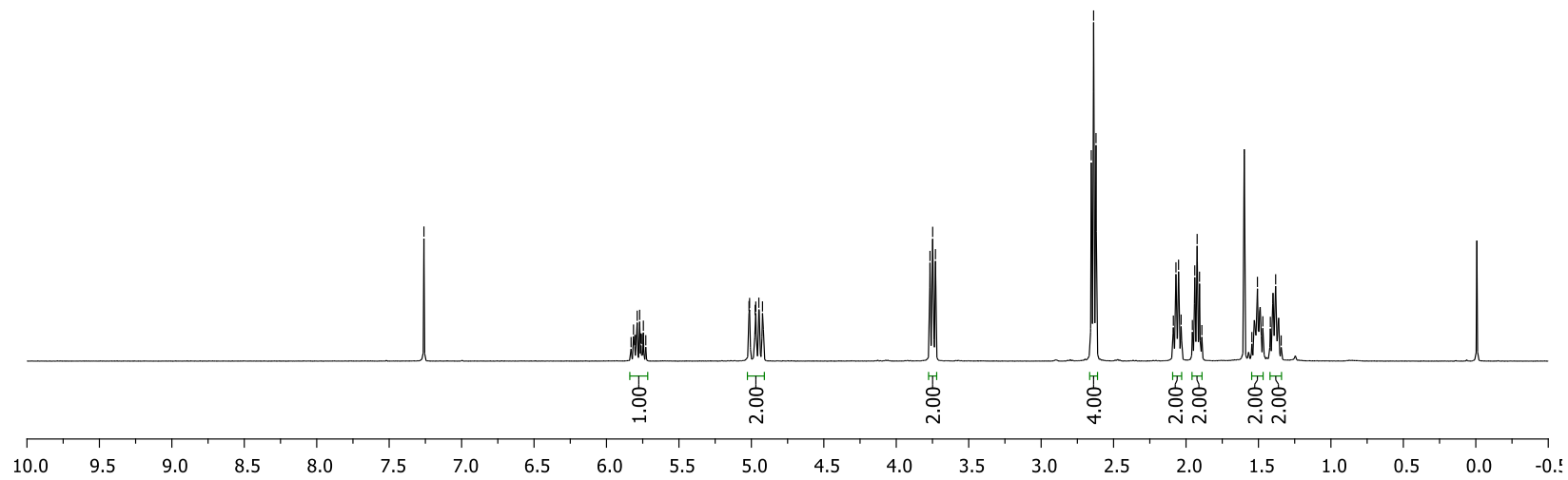

\begin{tabular}{|c|c|c|c|c|}
\hline 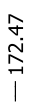 & $\begin{array}{l}\stackrel{\circ}{n} \\
\stackrel{\infty}{0} \\
\stackrel{m}{\sim}\end{array}$ & 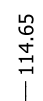 & 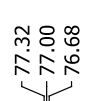 & 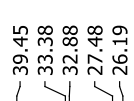 \\
\hline
\end{tabular}

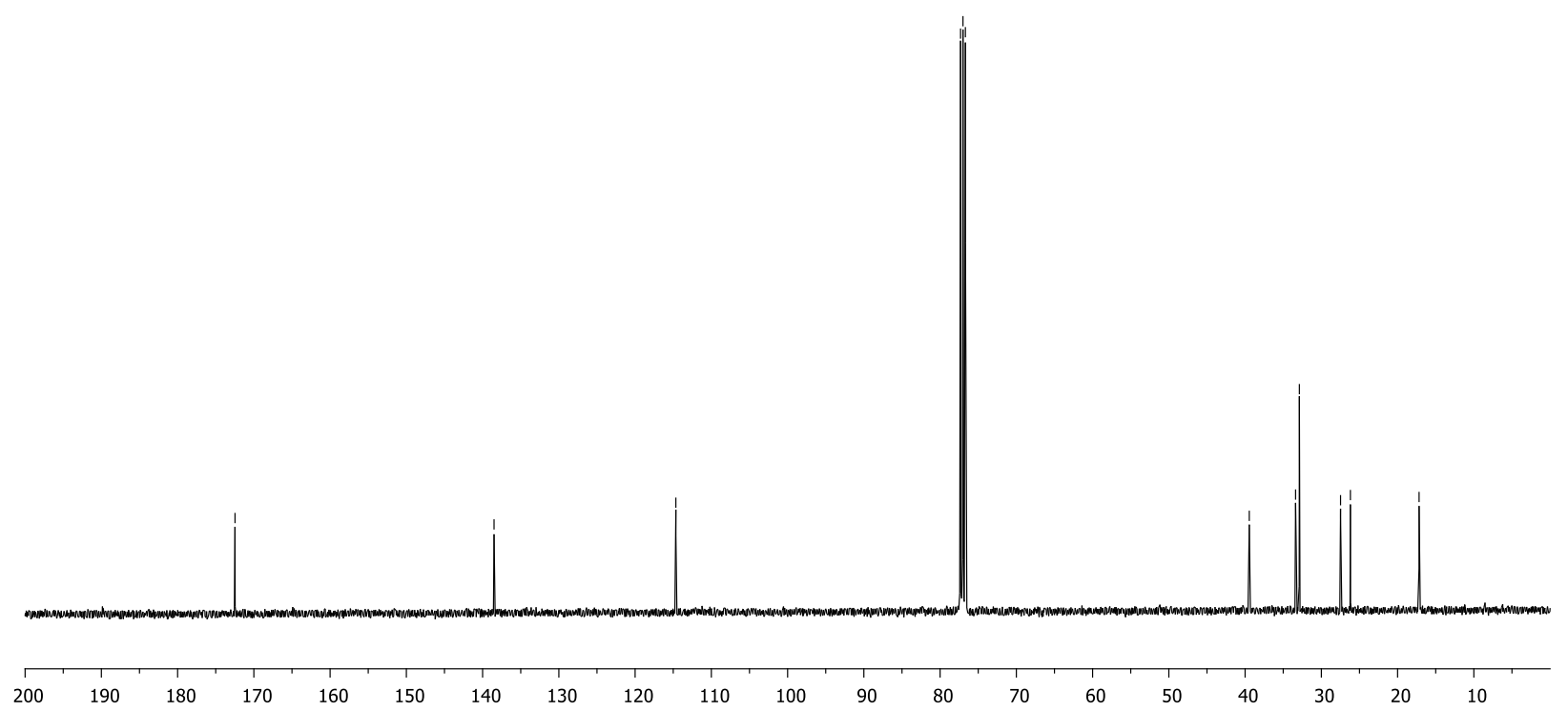


5-(2,6-dioxopiperidin-1-yl)pentanal (33)

ลָ.<smiles>O=CCCCCN1C(=O)CCCC1=O</smiles>

33
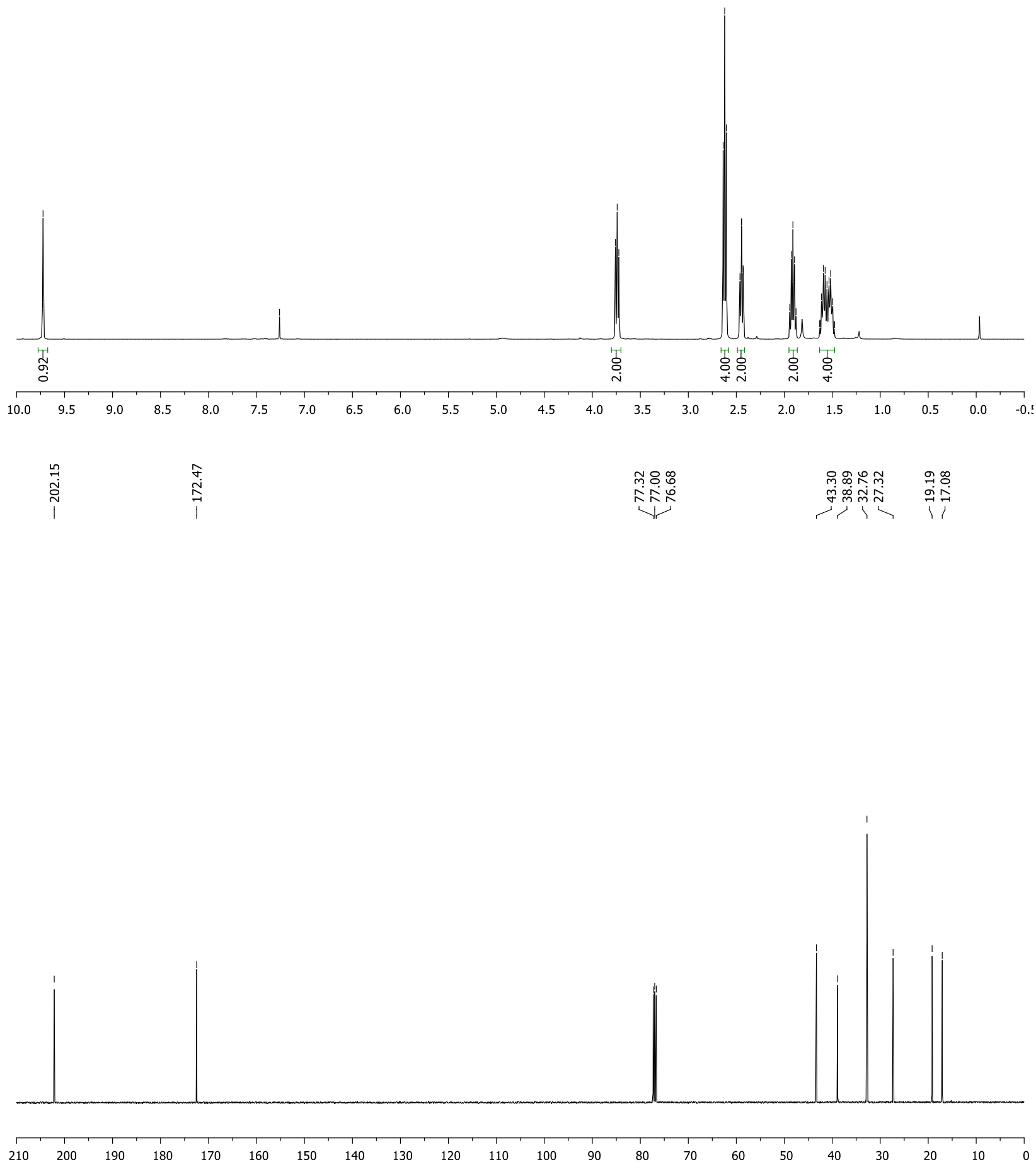


\section{1-(4-(1,3-dioxolan-2-yl)butyl)piperidine-2,6-dione (34)}

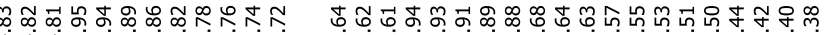<smiles>O=C1CCCC(=O)N1CCCCC1OCCO1</smiles>

34

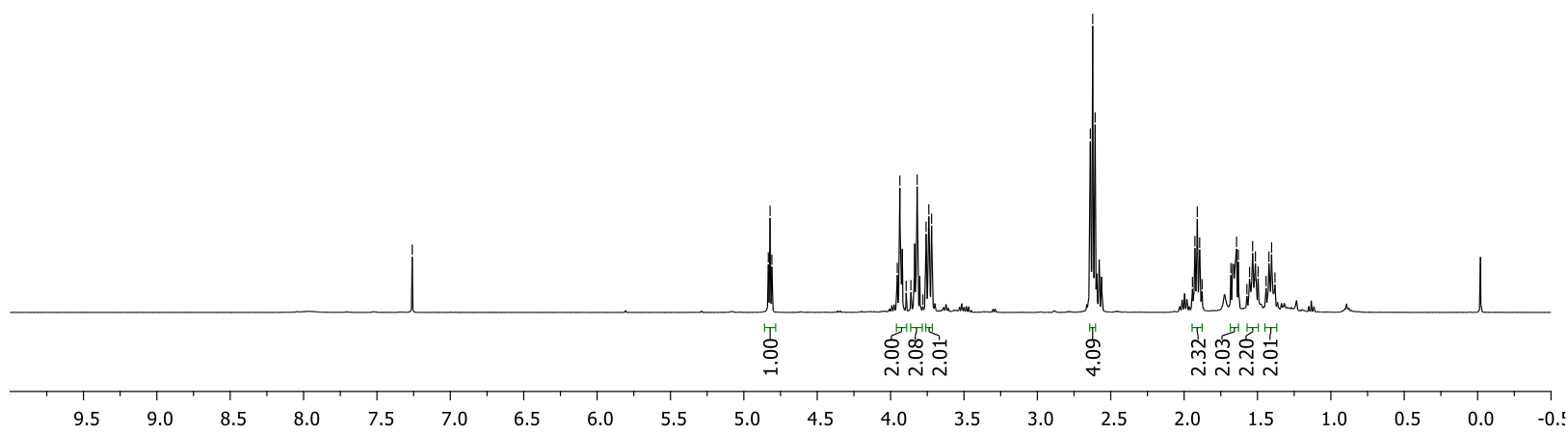

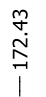

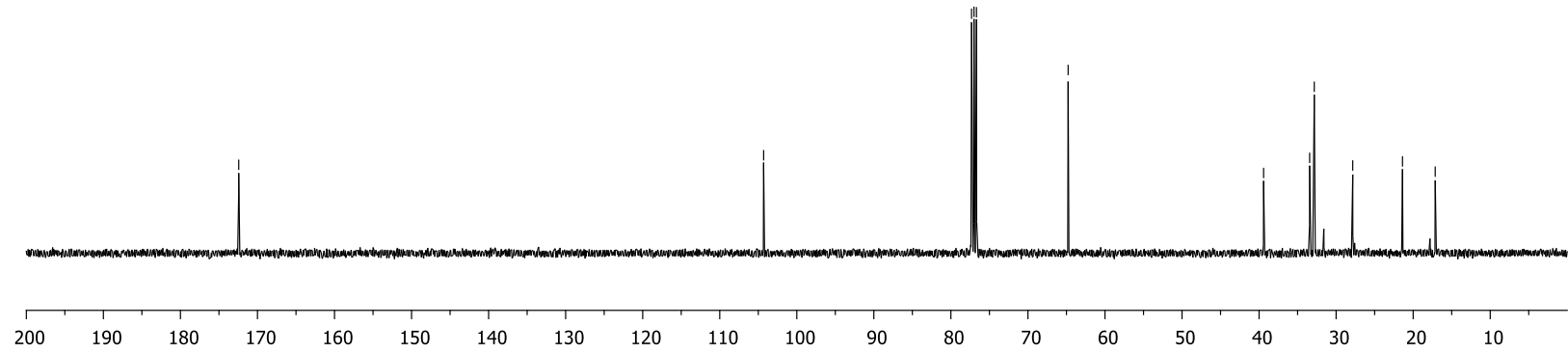


( \pm )-Epilupinine (36)<smiles>OCC1CCCN2CCCCC12</smiles>

36

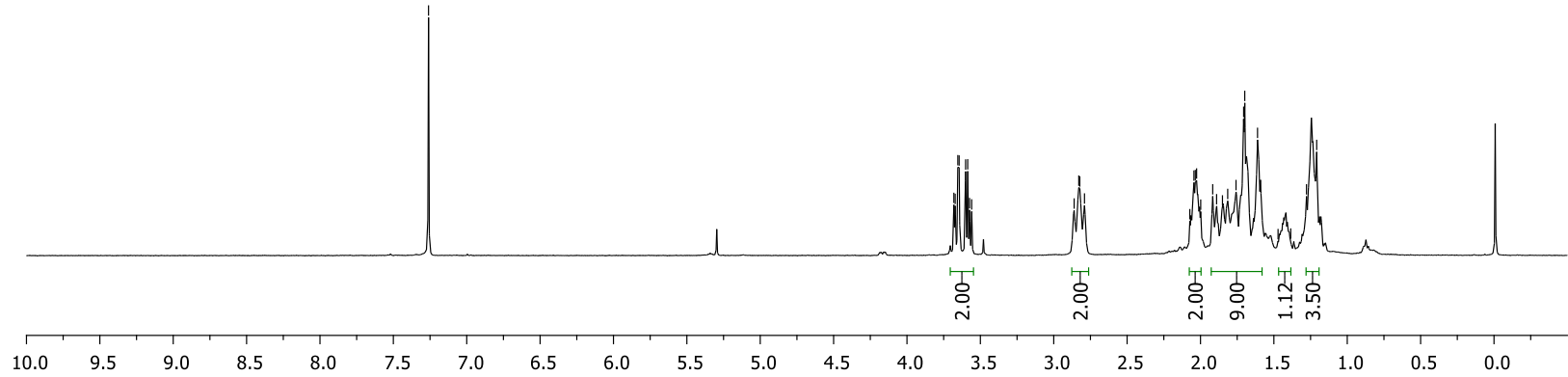

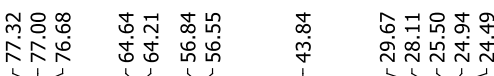

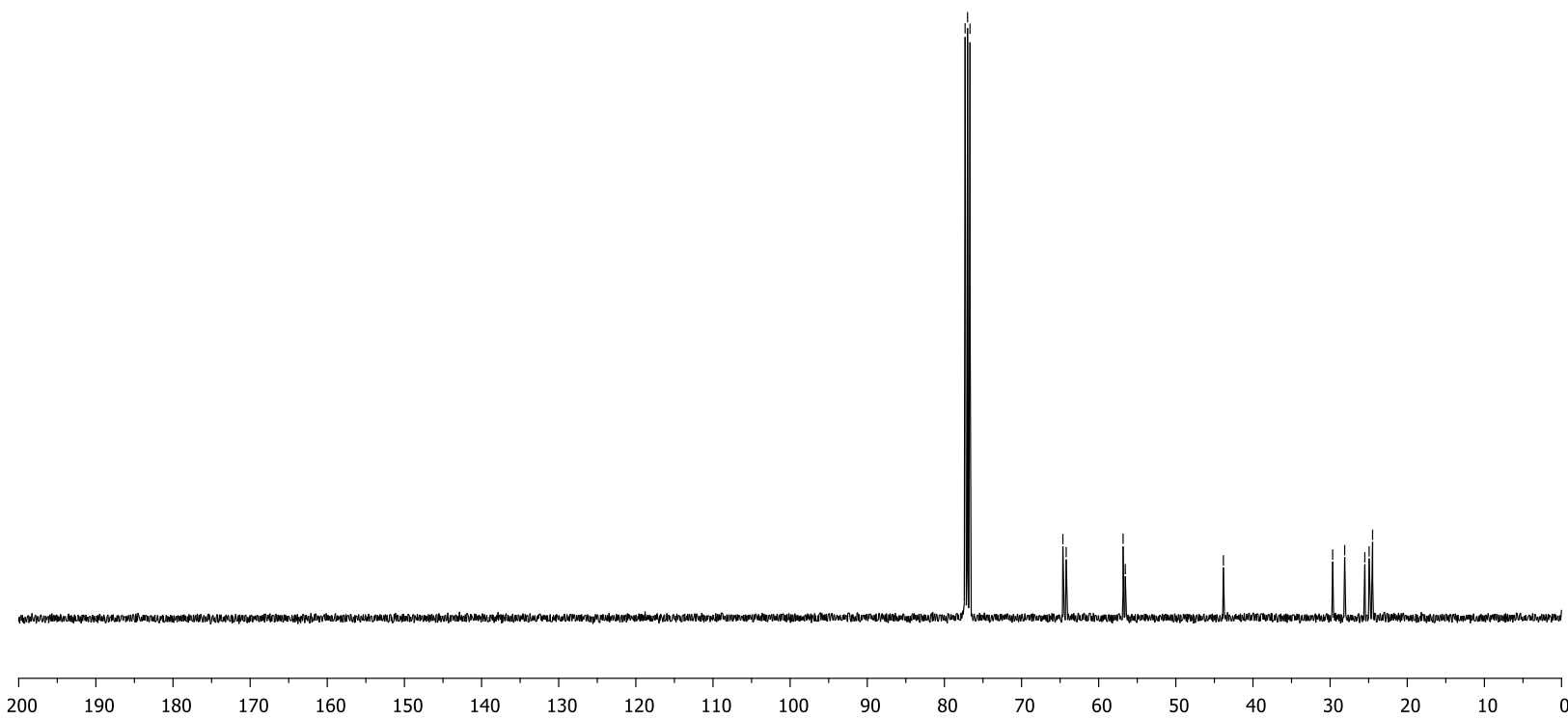


2-(3-oxobutyl)isoindoline-1,3-dione (38)
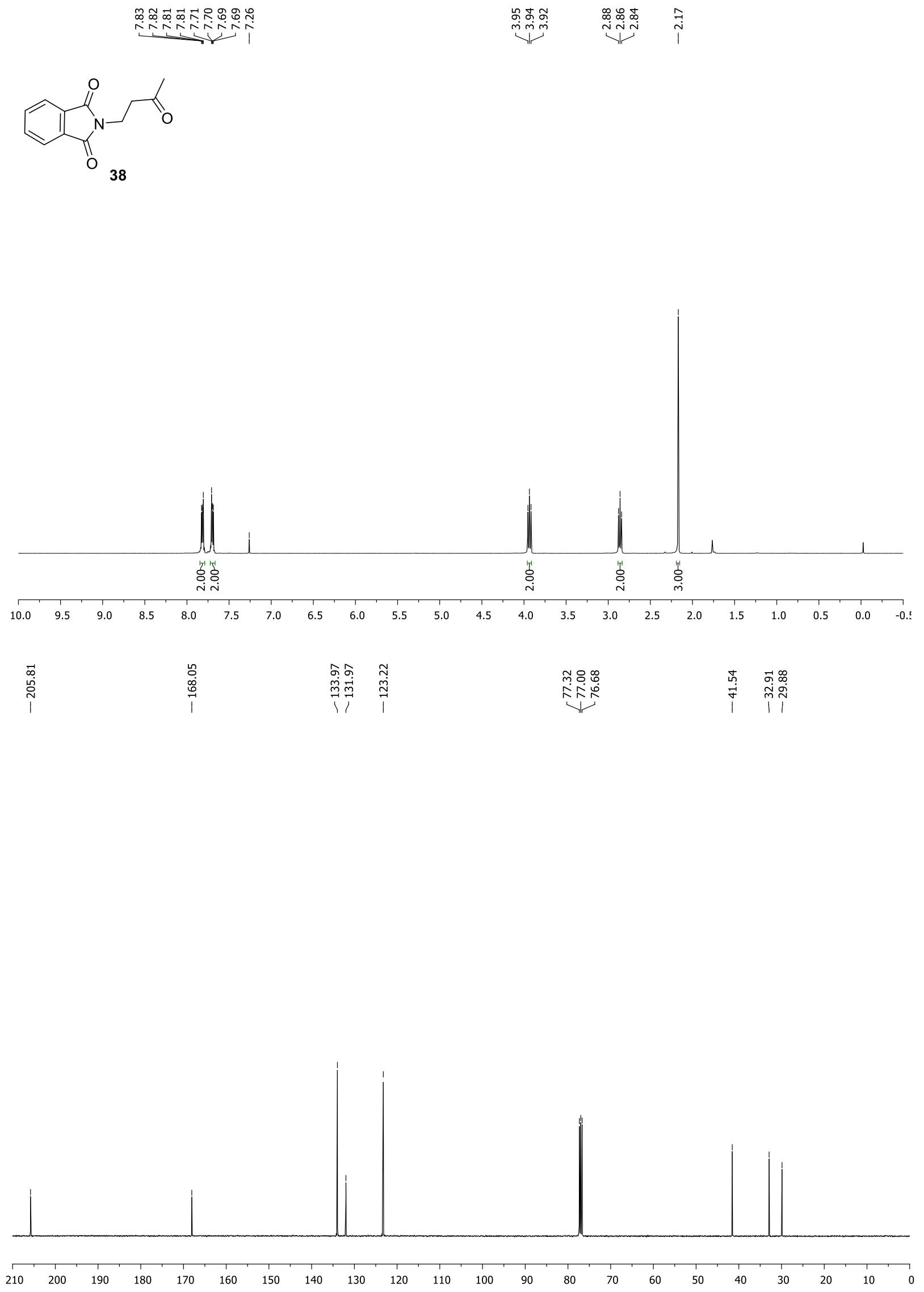
3,4-dihydropyrido[2,1-a]isoindole-2,6-dione (39)

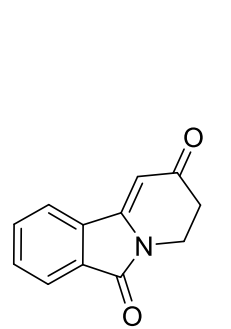

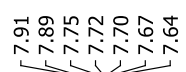

-1
$\dot{0}$
1

迄羿 굼

งิํํำ

39

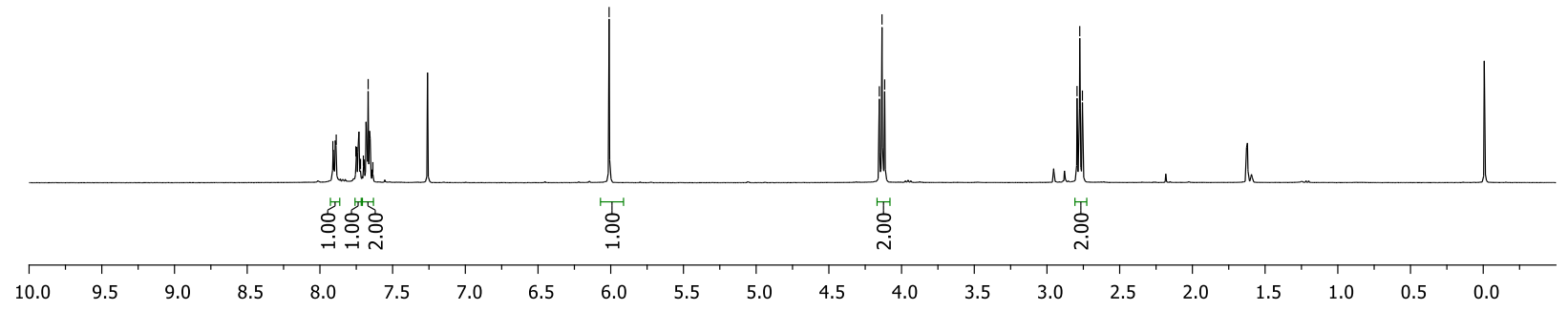

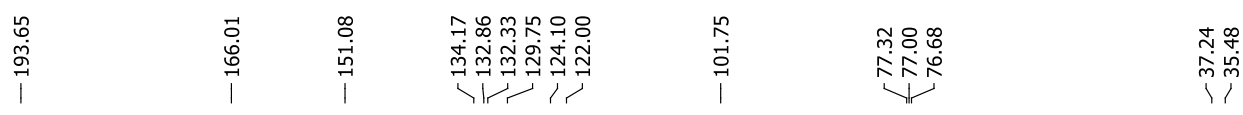

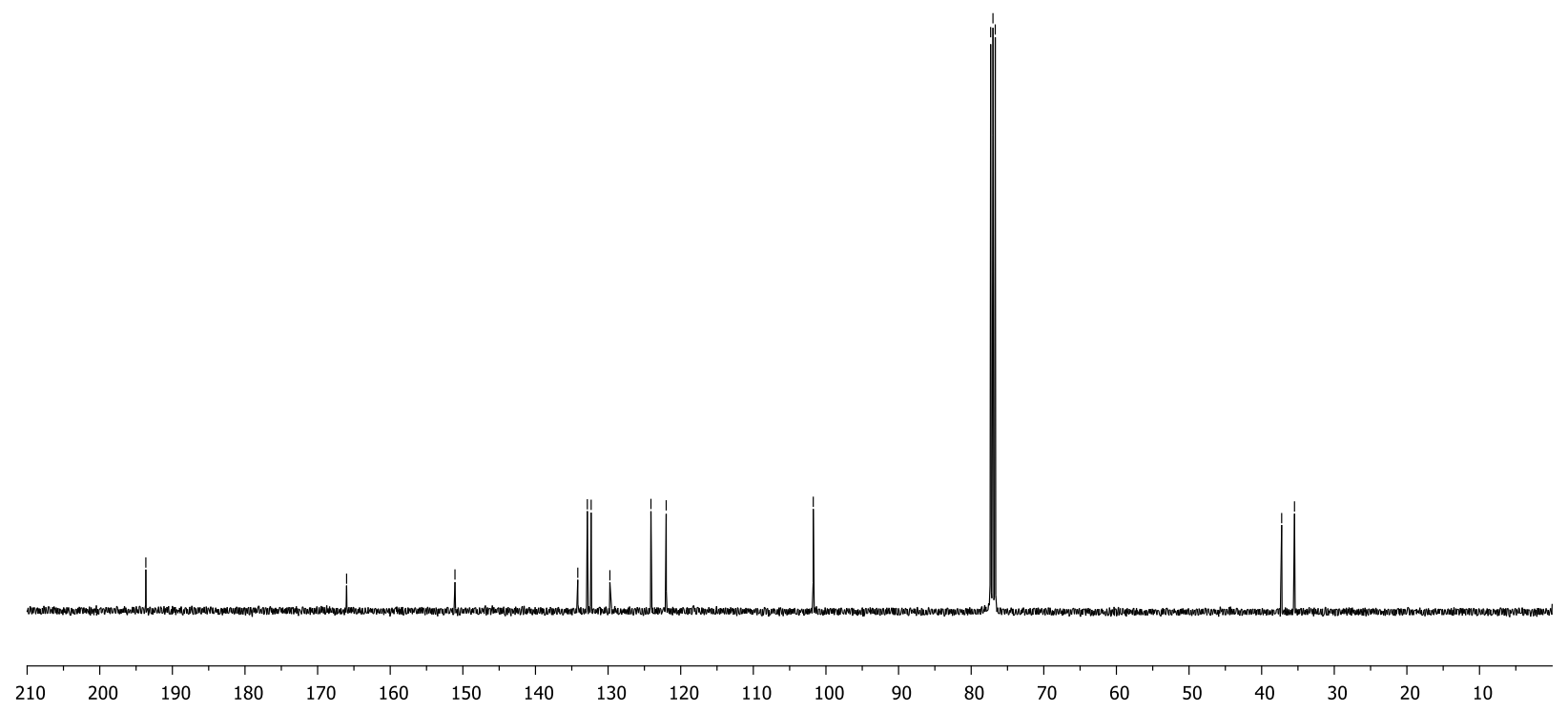


1,3,4,10b-tetrahydropyrido[2,1-a]isoindol-6(2H)-one (41)

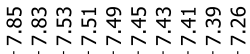

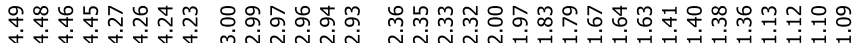

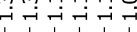<smiles>O=C1c2ccccc2C2CCCCN12</smiles>

41

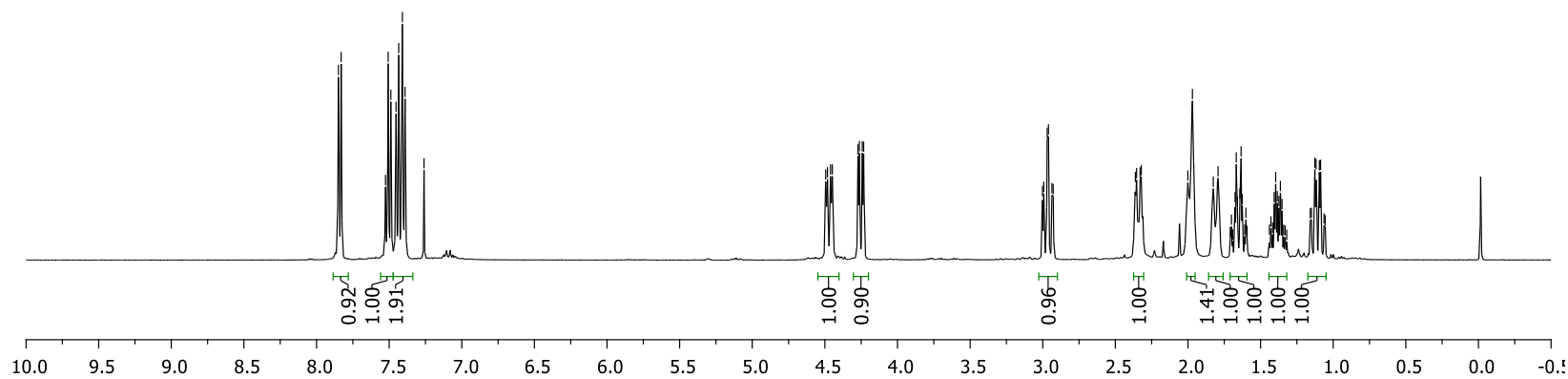

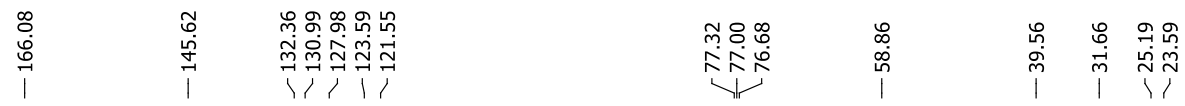

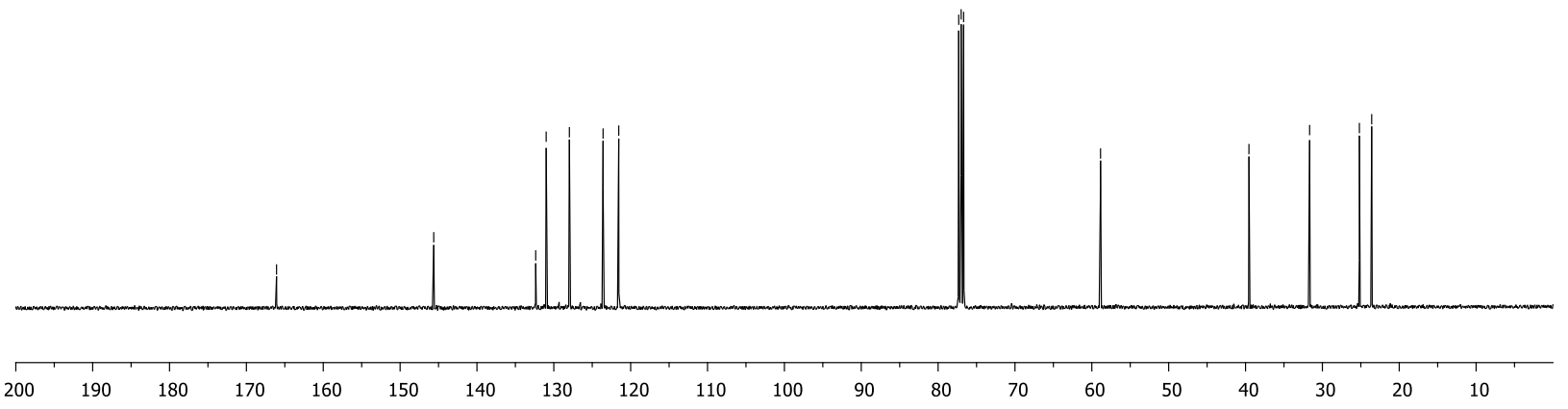




\section{References}

1. Rasapalli, S.; Kumbam, V.; Dhawane, A. N.; Golen, J. A.; Lovely, C. J.; Rheingold, A. L., Org. Biomol. Chem. 2013, 11, 4133-4137.

2. Beletskaya, I. P.; Tarasenko, E. A.; Khokhlov, A. R.; Tyurin, V. S., Russ. J. Org. Chem. 2010, 46, 461-467.

3. Flitsch, W.; Pandl, K., Liebigs Ann. Chem. 1987, 1987, 649-654.

4. Santiago, J. V.; Burtoloso, A. C. B., Eur. J. Org. Chem. 2018, 2018, 2822-2830.

5. Sibi, M. P.; Christensen, J. W., J. Org. Chem. 1999, 64, 6434-6442.

6. Goti, A.; Brandi, A.; Danza, G.; Guarna, A.; Donati, D.; De Sarlo, F., J. Chem. Soc., Perkin Trans. 11989, 1253-1258.

7. Boulahjar, R.; Ouach, A.; Matteo, C.; Bourg, S.; Ravache, M.; Guével, R. I.; Marionneau, S.; Oullier, T.; Lozach, O.; Meijer, L.; Guguen-Guillouzo, C.; Lazar, S.; Akssira, M.; Troin, Y.; Guillaumet, G.; Routier, S., J. Med. Chem. 2012, 55, 9589-9606.

8. $\mathrm{Yu}, \mathrm{H} . ;$ Zhang, G.; Huang, H., Angew. Chem. Int. Ed. 2015, 54, 10912-10916.

9. a) Gade, A. B.; Patil, N. T., Org. Lett. 2016, 18, 1844-1847; b) Padwa, A.; Waterson, A. G., J. Org. Chem. 2000, 65, 235-244.

10. Martin, S. F.; Chen, H.-J.; Courtney, A. K.; Liao, Y.; Pätzel, M.; Ramser, M. N.; Wagman, A. S., Tetrahedron 1996, 52, 7251-7264.

11. a) Hofstra, J. L.; Cherney, A. H.; Ordner, C. M.; Reisman, S. E., J. Am. Chem. Soc. 2018, 140, 139-142; b) Suga, H.; Hashimoto, Y.; Yasumura, S.; Takezawa, R.; Itoh, K.; Kakehi, A., J. Org. Chem. 2013, 78, 10840-10852.

12. Park, Y.; Schindler, C. S.; Jacobsen, E. N., J. Am. Chem. Soc. 2016, 138, 14848-14851.

13. Beliaev, A.; Wahnon, J.; Russo, D., Org. Process Res. Dev. 2012, 16, 704-709.

14. Maity, A. K.; Roy, S., J. Org. Chem. 2012, 77, 2935-2941. 